\title{
Pore water pressure and total horizontal stress response to EPBM tunnelling in London Clay
}

\author{
M. S. P. WAN* J. R. STANDING $\dagger$, D. M. POTTS $\uparrow$ and J. B. BURLAND $\dagger$
}

\begin{abstract}
The ground response, in terms of surface and subsurface displacements, to twin-bore Crossrail tunnel construction beneath a research monitoring site in Hyde Park, London, using earth-pressure-balance machines (EPBMs) in London Clay, has recently been reported in two companion papers by the authors. This third paper presents and discusses corresponding changes in pore water pressure and total horizontal stress measured using multi-level piezometers and pushed-in spade cells. The three papers together provide a comprehensive and completely unique field monitoring case history of the shortterm ground response to EPBM tunnelling in London Clay, making them invaluable for validating future numerical analyses. The fully grouted vibrating-wire piezometers were able to measure the rapid pore water pressure changes around the tunnels as they were constructed. Five distinct immediate pore water pressure responses are identified, induced by different stages of the tunnel drives as the EPBMs approached and passed the instruments. The responses are correlated with tunnel-boring machine operation variables and a postulated arching mechanism, identified for the first time through field measurements. The sense and magnitude of changes in horizontal total stress were reasonable and are correlated with overall pore water pressure changes. Both responses are linked where possible with measured subsurface displacements and generally correlate well, at least qualitatively. Limitations to the measurements and influencing factors are also discussed.
\end{abstract}

KEYWORDS: field instrumentation; monitoring; pore pressures; tunnels \& tunnelling

\section{BACKGROUND}

Tunnel construction induces displacements, total stress changes and excess pore water pressures in the surrounding ground. In saturated ground of low permeability, the immediate response to the resulting changes in total stress is essentially undrained, causing rapid changes in pore water pressure. This is followed by a gradual drained response as pore water pressures equalise towards a steady state governed by both the far-field and soil-tunnel-lining interface drainage boundary conditions. Understanding the development of excess pore water pressures induced by tunnel construction is of significant interest to asset owners, engineers and researchers because: $(a)$ long-term ground settlements are largely controlled by the dissipation of the excess pore water pressures; and $(b)$ they provide a means of validating/calibrating complex numerical analyses modelling tunnels. Construction of the twin-bore Crossrail tunnels provided an opportunity to monitor the development of pore water pressure and total stress changes, in conjunction with ground displacements, during their construction by earth-pressure-balance machines (EPBMs) in London Clay.

Measurements of the development of pore water pressure and total stress induced by tunnelling in soft or stiff clays have not been reported in the literature as extensively as corresponding ground displacements. Published accounts of field

Manuscript received 13 December 2017; revised manuscript accepted 6 June 2018. Published online ahead of print 16 July 2018. Discussion on this paper closes on 1 October 2019, for further details see p. ii.

* Geotechnical Consulting Group LLP, London, UK

(Orcid:0000-0001-5290-8449).

$\dagger$ Department of Civil and Environmental Engineering, Imperial College, London, UK. pore water pressure measurements during shield tunnelling include those in soft clays in the UK (Glossop, 1978), Canada (Palmer \& Belshaw, 1980), Singapore (Lo et al., 1988; Shirlaw \& Doran, 1988), China (Yi et al., 1993; Lee et al., 1999) and Taiwan (Hwang et al., 1995). Pore water pressure measurements have also been taken in centrifuge test modelling of tunnelling in soft clay (Mair, 1979; Grant, 1998; Dival et al., 2017). More cases exist for tunnelling in London Clay with pore water pressure measurements taken at various sites: Regent's Park, central London, during hand-driven openshield tunnel construction (Barratt \& Tyler, 1976); Heathrow, west London, during tunnel construction using the sprayed concrete lining method (New \& Bowers, 1994; Clayton et al., 2000); St. James's Park, central London, during and after open-face shield tunnelling (Nyren, 1998); West Ham, east London, during closed-face shield tunnelling (Macklin \& Field, 1999); and at Dagenham, east of London, during EPBM tunnelling (Standing \& Selemetas, 2013).

This paper focuses on the measured immediate ground response in terms of pore water pressure and total horizontal stress changes induced by the passage of the two Crossrail EPBMs in London Clay. Measuring pore water pressure changes at various elevations and offsets to tunnel construction is of significant interest as this can facilitate the understanding of the extent of the immediate response and the spatial distribution of the generated excess pore water pressures. At an instrumented 'greenfield' site in Hyde Park, London, pore water pressures and total stress changes were measured in the close vicinity of the Crossrail tunnel construction by: (a) multi-level vibrating-wire (VW) type piezometers installed in boreholes, and $(b)$ pushed-in total stress spade cells (with built-in piezometers). These piezometers formed part of an extensive instrumentation and monitoring scheme for measuring the tunnelling-induced ground response. The short-term surface and subsurface ground displacements are presented and discussed respectively in two companion papers (Wan et al., 2017a, 2017b) 
and have, where possible, been correlated with the changes in pore water pressure and total stress.

During the assessment of the pore water pressure data in conjunction with the EPBM operation variables it became evident that a more realistic interpretation of the data could be achieved by postulating an arching mechanism around the shield as it advanced. Ground arching was defined and discussed by Terzaghi (1943) and although often associated with granular soils, it can equally develop in more continuum-like clay soils. Essentially the mechanism involves a yielding region of a soil mass (in the tunnelling context, that part moving into the face or tail skin region) where in the short term total stresses reduce, and a more stationary region around the yielding part of the soil mass, where total stresses increase. More recently, Lee et al. (2006) investigated an arching mechanism around tunnel excavation by finite-difference modelling and centrifuge modelling, while Jiang \& Yin (2012) investigated the development of ground arching around tunnel excavation using the discrete-element method.

In low-permeability clays such as London Clay, a decrease/increase in total stress results, under undrained conditions, in a broadly equal decrease/increase in pore water pressure. Arching mechanisms are referred to when describing the piezometer and spade cell responses to tunnelling and are discussed more fully in the section entitled 'Mechanisms of EPBM tunnelling-induced pore water pressure changes and ground arching'. The results presented in this paper strongly suggest an arching mechanism, identified for the first time through field measurements, for an advancing EPBM in London Clay.

The Hyde Park field monitoring work formed part of an extensive research project investigating the effect of tunnelling on existing tunnels, which also involved in-tunnel measurements, structural testing of bolted cast-iron segments, numerical analyses and advanced laboratory soil testing (Standing et al., 2015; Avgerinos et al., 2016, 2017, 2018; Afshan et al., 2017; Tsiampousi et al., 2017; Yu et al., 2017). As with the second companion paper (Wan et al., $2017 \mathrm{~b}$ ), in this current paper the intention is to provide sufficient background information such that it can be read and understood independently of the companion papers. Many more details relating to the Crossrail project, site geology, instrumentation layout and the EPBMs used can be found in them (especially Wan et al. (2017a)). These details have been omitted here in order to avoid needless repetition, but where necessary the reader is directed to appropriate sections and figures in the companion papers.

A primary intention of the three papers is to provide comprehensive, research-quality field-monitoring data, in conjunction with detailed information on the EPBMs, their progression and their operation variables, to enable those performing advanced numerical studies to be able to validate their analyses and calibrate their constitutive models. Detailed results from the soil testing of high-quality samples taken during the installation of instruments at Hyde Park are currently being written up in a separate paper.

\section{CROSSRAIL TUNNELLING WORK AND SITE GEOLOGY AND HYDROGEOLOGY}

The westbound and eastbound Crossrail tunnel drives beneath Hyde Park were part of the western tunnelling section from the Royal Oak portal to Farringdon station. The Hyde Park research site was set up close to where the Crossrail tunnels pass beneath the existing Central Line tunnels under Bayswater Road, just east of Lancaster Gate underground station. The relative positions of the tunnels are shown in Fig. 1, their respective axis depths are about $24 \mathrm{~m}$
(Central Line) and $34.5 \mathrm{~m}$ (Crossrail) below ground level (mbgl).

The EPBMs used to construct the Crossrail tunnels were $7 \cdot 1 \mathrm{~m}$ in diameter with tapered shields of length $11 \mathrm{~m}$. The tunnel lining rings, with inner and outer diameters of $6.2 \mathrm{~m}$ and $6.8 \mathrm{~m}$, respectively, and length of $1.6 \mathrm{~m}$, were formed of seven precast concrete bolted segments and a key-piece, erected within the shield body. The annulus void between the tunnel lining extrados and the excavated ground was filled with a two-part grout, usually termed the 'tail-skin grout' or 'tail grout'. Details of the EPBMs used are given by Wan et al. (2017a: Fig. 5 and pp. 423-424). Within the EPBMs comprehensive systems of instrumentation allowed operation variables to be monitored continuously.

The stratigraphy beneath the Hyde Park site is typical of central London with made ground and Terrace Gravels overlying the descending sequence of the London Clay Formation (LCF), Lambeth Group, Thanet Sand and Chalk bedrock. The detailed stratigraphy is shown and described by Wan et al. (2017a: Fig. 2) and that in the vicinity of the Central Line tunnels (division B2 of the LCF) and the deeper Crossrail tunnels (crown in division B2 and invert within the more permeable A3ii) are marked in this paper on the cross-sections in Fig. 2. More detailed information on the LCF divisions is given by King (1981).

Two aquifers are present at the instrumented site, as reported by many authors (e.g. Simpson et al., 1989). The Terrace Gravels constitute the upper aquifer, and the combined lower granular units of the Lambeth Group (Upnor Formation), the Thanet Sand and Chalk the lower aquifer. These aquifers are separated by the LCF and, if present, the upper and lower mottled beds of the Lambeth Group. During borehole drilling for the installation of the instrumentation, the upper water table was established to be about $4-5 \mathrm{mbgl}$ within the Thames Gravels, fluctuating by small degrees with season.

The deep water table was historically artesian but is now much lower owing to excessive abstraction activities in the early 1900s. Following the 'Gardit' (general aquifer research development and investigation team) strategy the water table is maintained below its natural level by controlled abstraction (Jones, 2007). As a result, the LCF is under-drained. An example of such a profile at Waterloo is given by Wright (2013) and was also observed at this site in the steady-state pore-water pressure profile measured by one of the 'greenfield' multi-level VW piezometers and the standpipe piezometers (see Fig. 3(a)).

\section{FIELD MONITORING}

\section{Field instrumentation layout and installation}

The instrumentation layout shown in Fig. 1 was designed specifically to monitor the subsurface ground responses induced by the construction of the westbound and eastbound tunnels. Installations for measuring pore water pressures include three boreholes containing multi-level VW piezometers, and one with a conventional standpipe piezometer. There are also four boreholes with combined total stress transducer-piezometer spade cells. Cross-sections A-A and B-B marked in Fig. 1 indicate the relative positions of the different types of piezometer sensors and the Crossrail tunnels and are shown in Figs 2(a) and 2(b).

Within Hyde Park, two piezometer boreholes (HP32 and HP33), with six piezometer sensors at various depths in each, were installed above and adjacent to the Crossrail eastbound tunnel. One spade cell (HP39) was installed 1.5 m directly above the same eastbound tunnel crown and three others (HP35, HP36 and HP37) either side of it, all being at tunnel axis level (Fig. 2(a)). Under the southern pavement of 


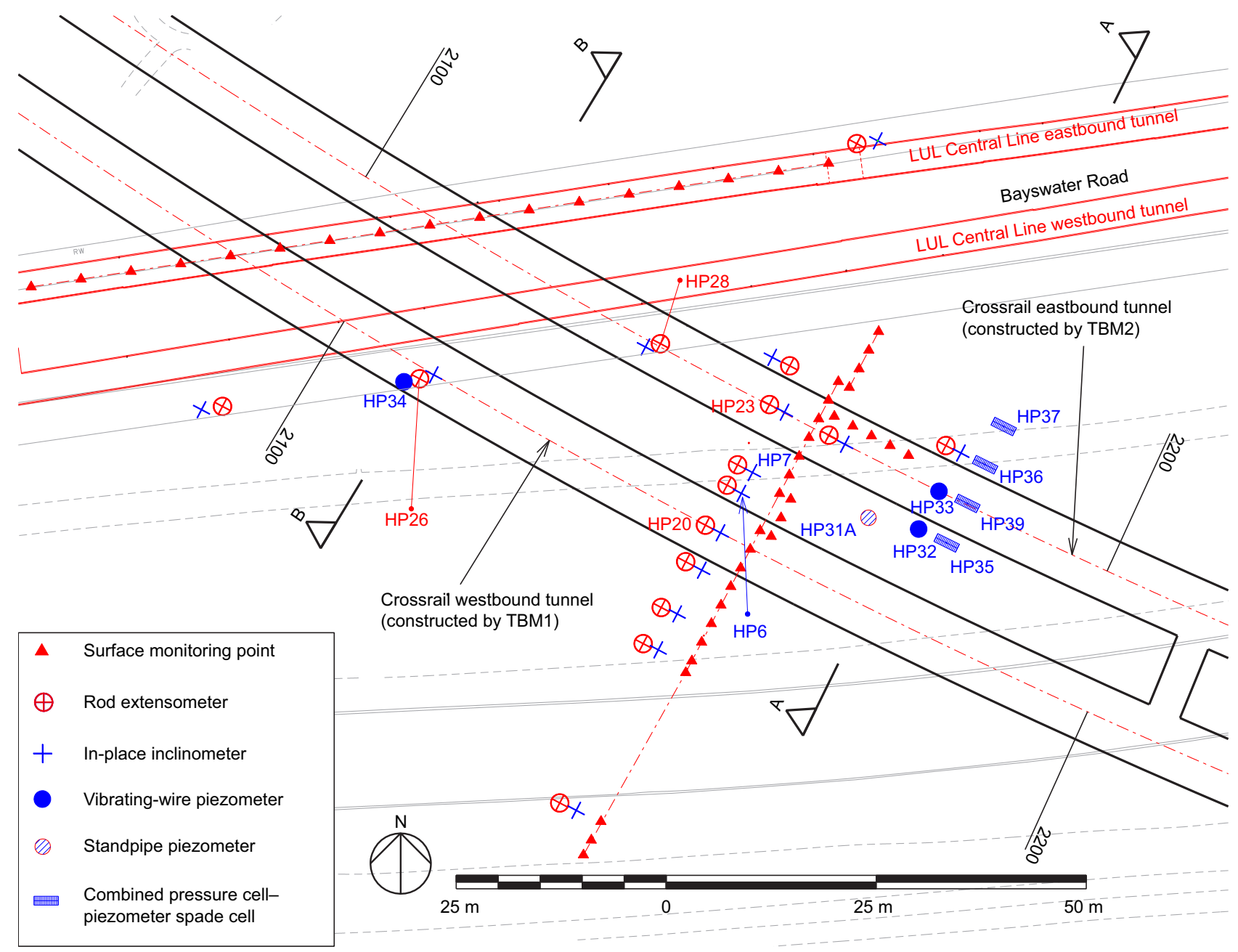

Fig. 1. Instrumentation layout plan

Bayswater Road, there is one multi-level piezometer borehole (HP34), containing six sensors, directly above the Crossrail westbound tunnel (at depths down to $2 \mathrm{~m}$ above crown level) and at a horizontal offset of $5 \mathrm{~m}$ from the existing Central Line westbound tunnel extrados (Fig. 2(b)).

The multi-level piezometers were installed in the boreholes using a fully grouted method where the VW sensors (manufactured by Soil Instruments Ltd), equipped with high-air-entry filters and having a measurement range of $300 \mathrm{kPa}$ or $500 \mathrm{kPa}$, were fixed at pre-determined levels within the borehole before backfilling with a suitable cement-bentonite grout. Wan \& Standing (2014a) discuss in detail the installation, including the selection of suitable grout mix proportions. Wan \& Standing (2014b) present the background and pre-construction pore water pressures measured by these piezometers and the resulting steady-state pore water pressure profiles at the site. Good agreement between the measurements from the standpipe piezometer (HP31A) and the VW piezometers was demonstrated. Detailed analysis of the results also revealed the potential influence of claystones present in the LCF on the groundwater regime and the performance of the multi-level piezometers. It was established that the three bottom-most piezometer sensors in HP33 were hydraulically interconnected due to a high concentration of claystones over the relevant depth range. Wan \& Standing (2014b) also present a reduced pore water pressure profile at the current site measured close to the existing Central Line tunnels (constructed with segmental cast-iron linings in the nineteenth century), suggesting that they have been draining the surrounding ground (LCF).

The spade cell type installed at the site (also manufactured by Soil Instruments Ltd) consists of a flat, rectangular (with a point at one end), spade-shaped oil chamber (formed by two $100 \mathrm{~mm}$ wide steel plates) connected to a VW pressure transducer with a measurement range of $2000 \mathrm{kPa}$. This measures total stresses acting on the pressure cell in the direction perpendicular to the spade surface. In-built at the top of one side of the spade is a porous filter, which is connected to a separate VW pressure transducer, so that the pore water pressure is measured independently at the same time. Each spade cell was installed by first drilling a borehole to a pre-determined depth (about $1 \mathrm{~m}$ above the target instrument depth). The spade cell, attached to a string of rods, was then lowered to the borehole base, before being pushed vertically to the target depth. The orientation of each spade cell was carefully adjusted so that the flat spade was parallel to the alignment of the eastbound Crossrail tunnel so as to make measurements of stress changes in the transverse direction. Wan \& Standing (2014b) describe the installation procedure.

From the literature it is well established that pushed-in spade cells provide overestimates of ground stresses. Tedd \& Charles (1981) investigated the measurement of in situ stress in London Clay by comparing horizontal stress measurements using spade cells with other in situ stress measuring instruments such as self-boring pressuremeters, whereas Tedd \& Charles (1983) and Ryley \& Carder (1995) compared the 


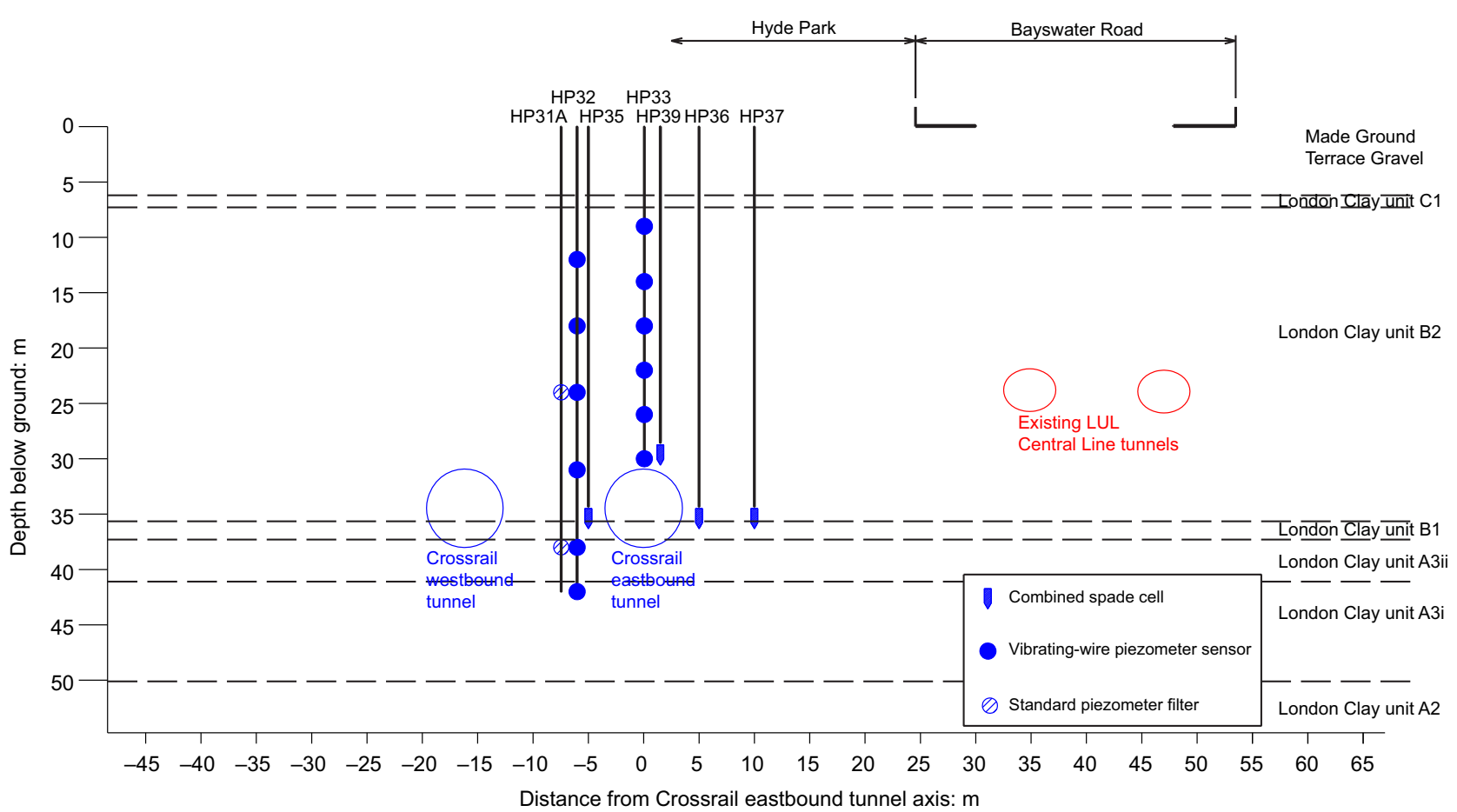

(a)

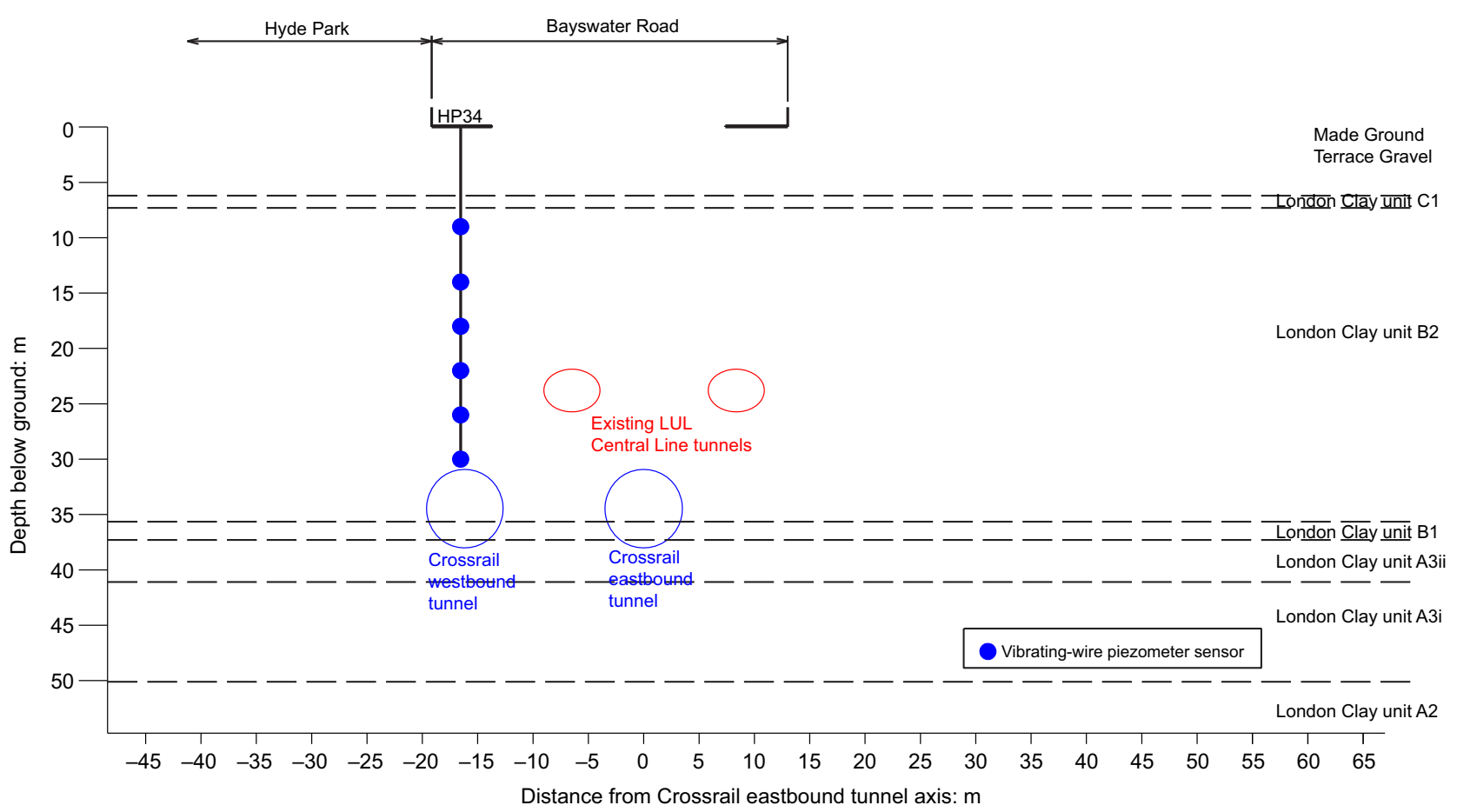

(b)

Fig. 2. (a) Cross-section of main array of piezometers and spade cells (section A-A). (b) Cross-section of piezometers in Bayswater Road (section B-B)

in situ overburden pressure with the vertical stress measured by spade cells installed horizontally, and found that the measured values need to be corrected by about half the undrained shear strength. Tedd et al. (1989) reviewed spade cell measurements from a number of sites in soft and stiff clays and found that generally the spade cells tend to over-read the actual total horizontal stress due to the complex local stresses on the spade surface induced by the installation pushing process. The over-read error based on all the above studies depends on the soil stiffness and can range widely from $0 \cdot 3$ to $2 \cdot 0$ times the undrained shear strength. It should be noted that the wide range of over-read factors determined from these studies can be attributed to a combination of errors associated with the 'true readings' that the spade cell measurements were compared with, and variability in the measurement of the undrained shear strength induced by different testing methods and sample dimensions. More recently, Richards et al. (2007) investigated the total vertical stress measured by horizontally installed spade cells under a box excavation in stiff Atherfield Clay, and reported that the over-read was about 0.35 times the undrained shear strength (determined from unconsolidated 


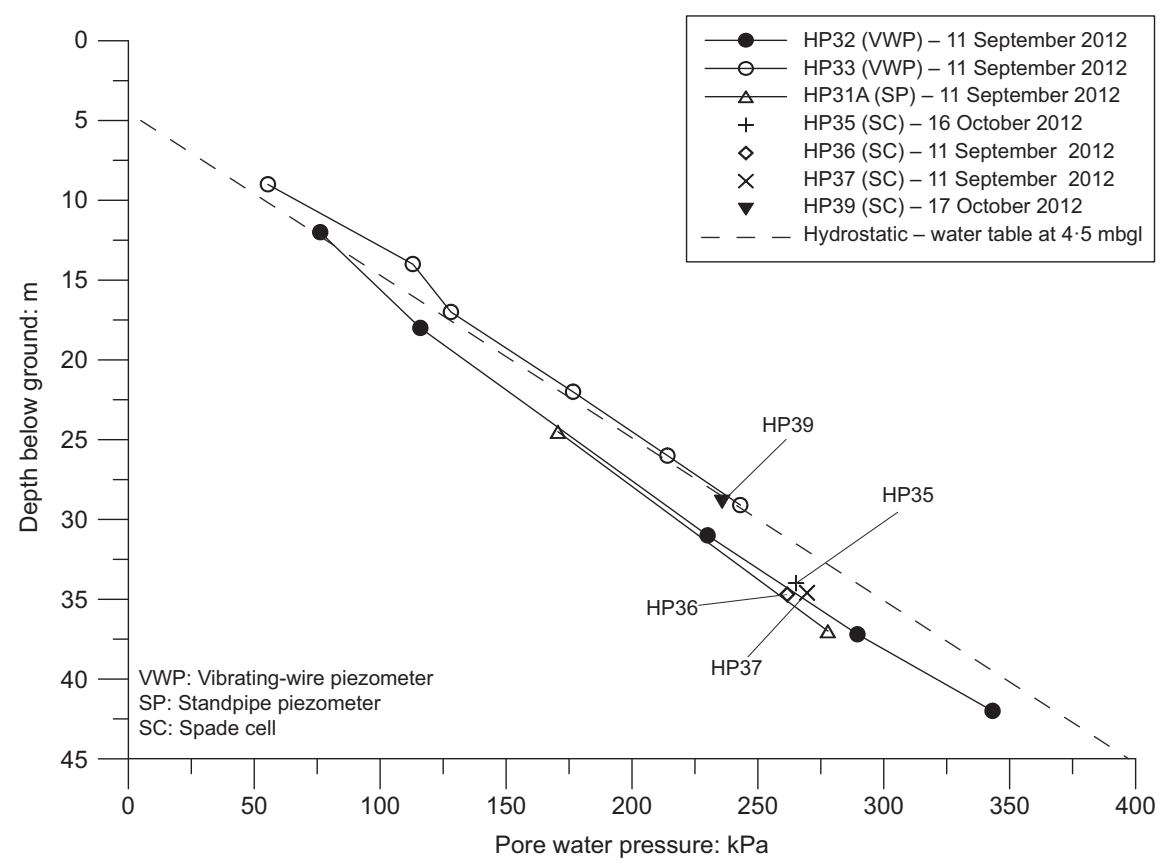

(a)

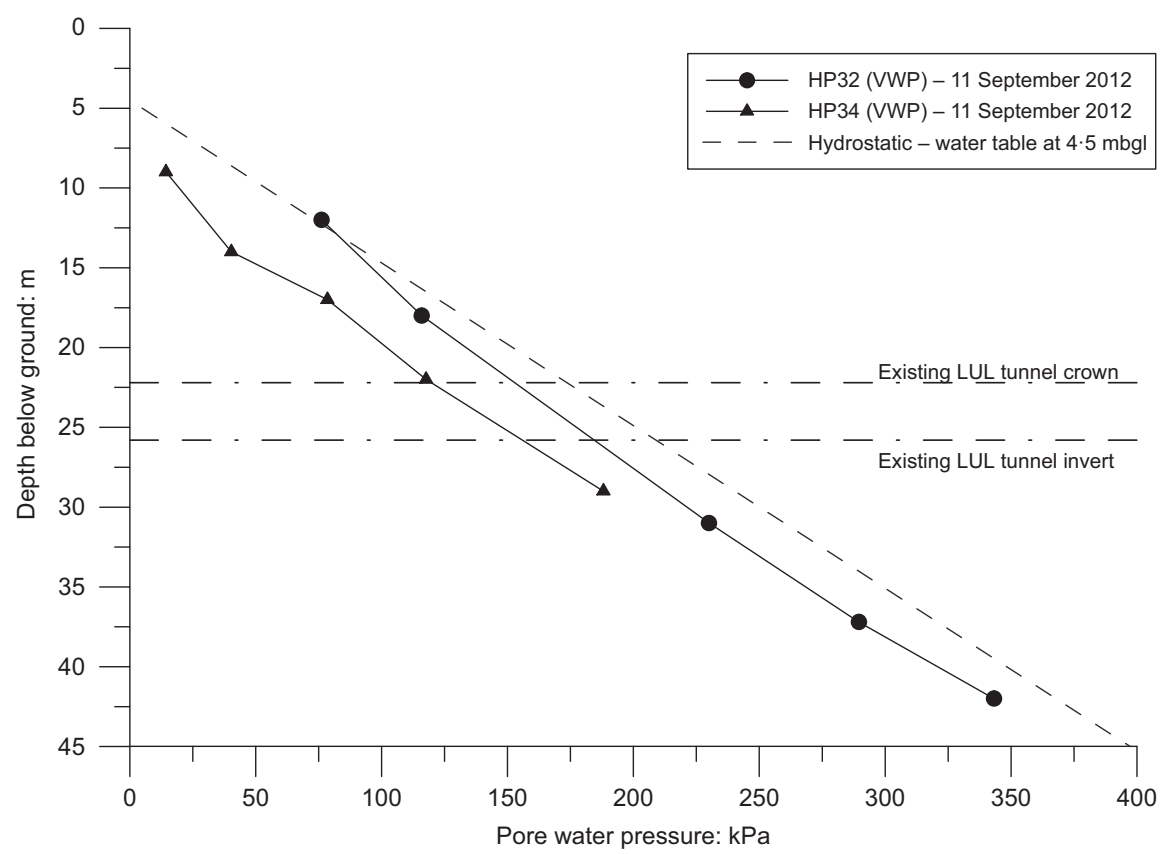

(b)

Fig. 3. Measured steady-state pore water pressures (after Wan \& Standing, 2014b): (a) in 'greenfield' ground by standpipe piezometer (HP31A), VW piezometers (HP32 and HP33) and spade cells (HP35, HP36, HP37 and HP39); (b) in the vicinity of the existing LUL running tunnels by VW piezometers (HP34) (HP32 also shown for reference)

undrained tests on $100 \mathrm{~mm}$ dia. samples and standard penetration test measurements) compared with the actual overburden pressure. They also found that the spade cells under-read the change (reduction) of vertical stress upon the removal of overburden due to excavation, but concluded that the discrepancy was a result of shear stress mobilised between the ground and the perimeter wall (wall adhesion) resisting the ground heave, rather than a result of overcompliance of the spade cell (i.e. it being insufficiently stiff compared with the ground).

In general, the spade cell would either over-read or under-read the change of total stress depending on the relative cell/soil stiffness. For the type of spade cell used at the Hyde Park site, the cell stiffness is high compared even with the small strain stiffness of London Clay. Therefore the spade cells would tend to over-read the horizontal stress changes induced by the tunnel construction, although it is difficult to quantify the over-read accurately.

Having discussed the various limitations of using spade cells, it is also worth commenting that when monitoring the three-dimensional ground response to EPBM tunnelling, there is little ambiguity in measuring displacements, as individual devices (e.g. extensometers and inclinometers) are specifically designed to measure respective vertical and horizontal components. However, when measuring pore water pressure and total stress changes, a greater appreciation of the three-dimensional effects is needed to interpret the field data correctly. 
Measured EPBM operation variables

The operation variables of the two EPBMs were recorded as they advanced. Wan et al. (2017a; Fig. 23) present the recorded face pressure, tail grout pressure and tail grout volume for both TBM1 and TBM2 (west- and eastbound construction, respectively) relating to when they were driven over about a $1 \mathrm{~km}$ distance beneath Hyde Park. In terms of rolling averages over ten lining rings, face pressures were maintained at about $200 \mathrm{kPa}$ for both TBM1 and TBM2, while tail grout pressures were slightly more variable but broadly maintained at about $100 \mathrm{kPa}$ for TBM1 and $200 \mathrm{kPa}$ for TBM2. The in situ total overburden pressure at tunnel axis level under Hyde Park is about $650 \mathrm{kPa}$.
The EPBM face pressures and tail grout pressures are examined in more detail for when the TBM drives were in close proximity of where the piezometers were installed. Figs 4(a) and 4(b) show the EPBM pressures, based on rolling averages over three rings, within $\pm 30 \mathrm{~m}$ of the piezometers and spade cells for TBM1 and TBM2, respectively. As both TBMs approached and passed the instruments, the face pressures were fairly consistent, ranging mostly between about $180 \mathrm{kPa}$ and $220 \mathrm{kPa}$, whereas the tail grout pressures were more variable, ranging from $40 \mathrm{kPa}$ to $240 \mathrm{kPa}$. As the tail grout pressures relate to the rear of the TBMs, for clarity, schematic representations of the TBMs in relation to the monitoring point are provided in Fig. 4 . When

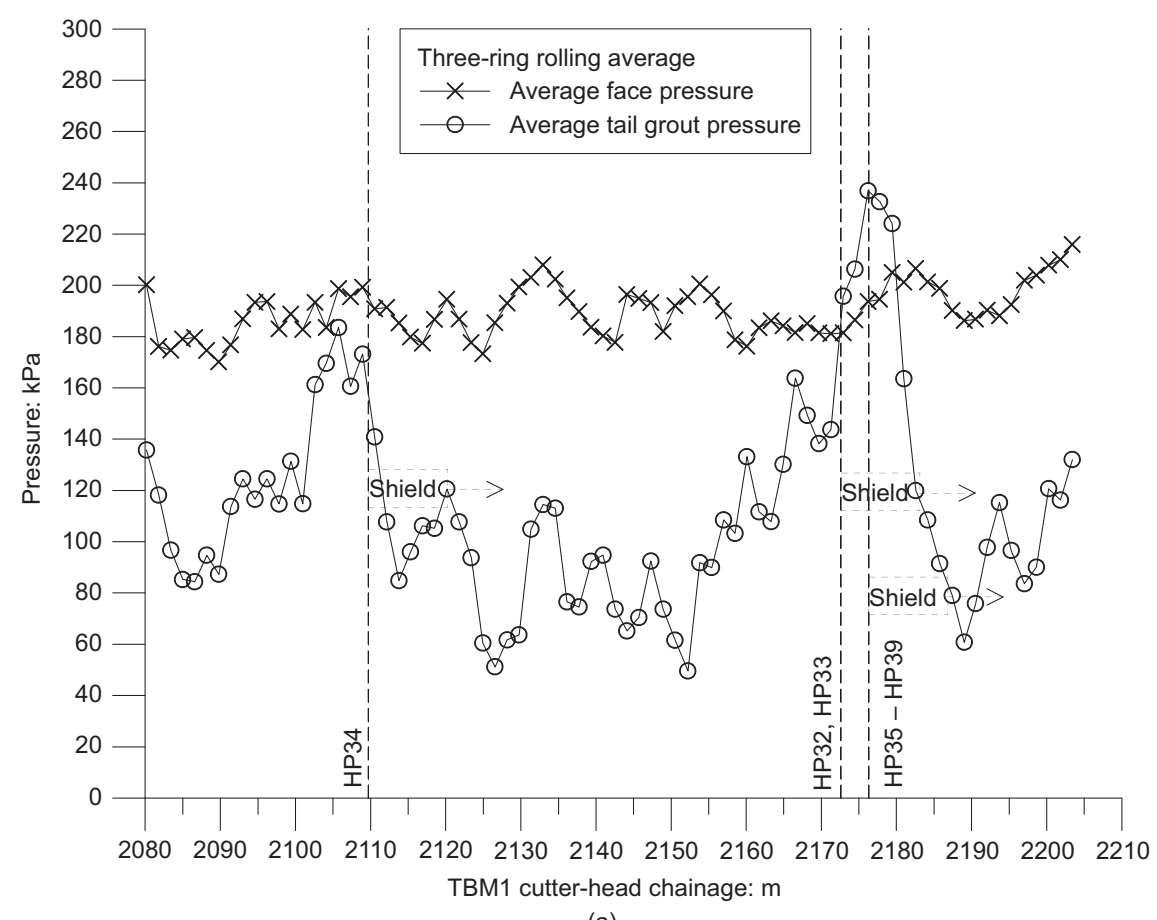

(a)

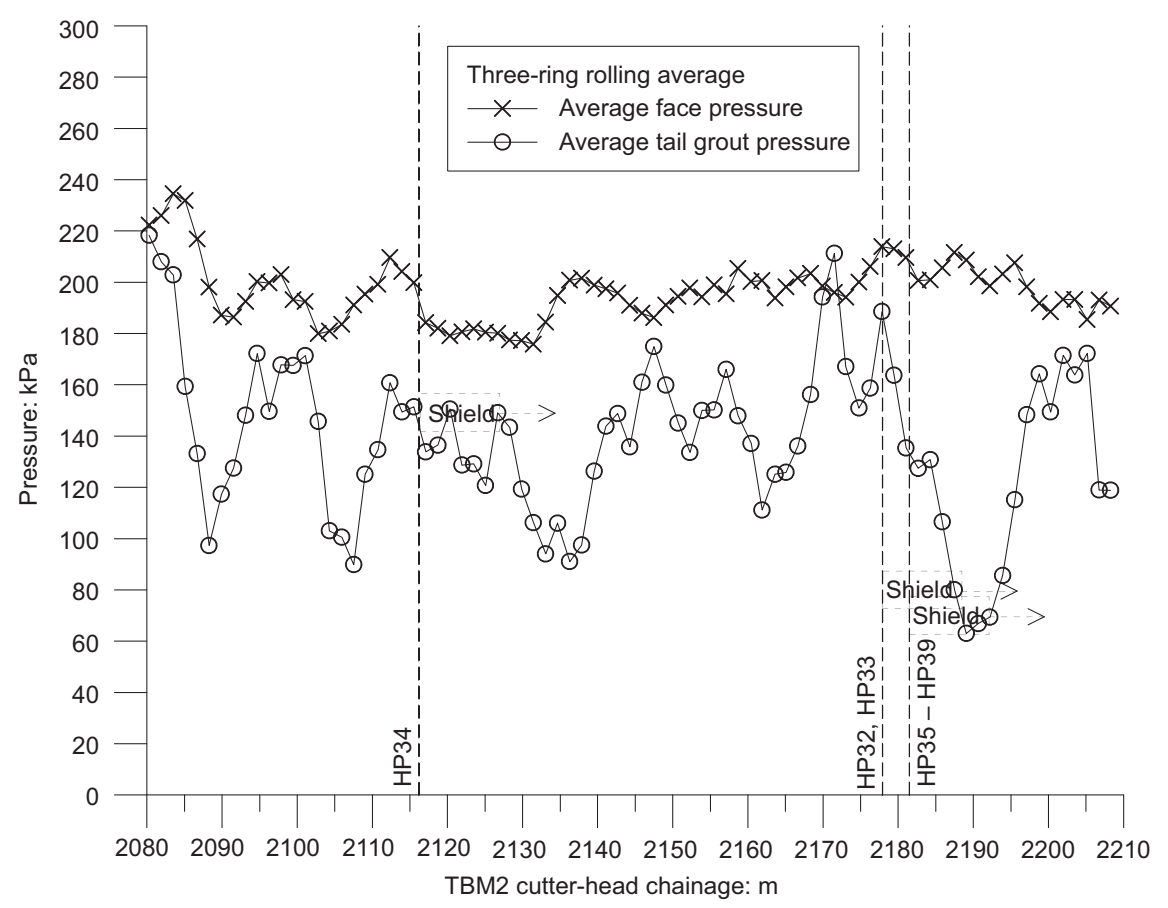

(b)

Fig. 4. Measured average face pressure and tail grout pressure of: (a) TBM1; (b) TBM2 
comparing EPBM pressures with measured pore water pressure and total stress changes, the EPBM values shown in Table 1 are adopted for each instrument.

\section{MONITORING RESULTS}

The pore water pressure and total stress monitoring data were divided into the same five periods used in the companion papers.

Period 1 - pre-construction (12 October 2011 to 19 November 2012).

Period 2 - construction of the westbound tunnel by TBM1 (19 November 2012 to 30 November 2012).

Period 3 - interim phase before TBM2 arrived

(30 November 2012 to 3 February 2013).

Period 4 - construction of the eastbound tunnel by TBM2

(3 February 2013 to 12 February 2013).

Period 5 - long-term monitoring (12 February 2013 onwards).

The sign conventions for presentation of the monitoring results are as follows.

(a) $x_{\mathrm{f}}$ is the longitudinal horizontal distance between the cutter-head and the monitoring point/line in question. $(-) x_{\mathrm{f}}$ means the cutter-head is approaching the monitoring point/line while $(+) x_{\mathrm{f}}$ means the cutter-head is progressing beyond the monitoring point/line.

(b) Positive $(+) y$ means the transverse horizontal distance from the tunnel axis to the left-hand side when looking in the direction of tunnel advancement.

(c) Negative $(-) z$ means the downwards vertical distance from the ground surface, but depth (mbgl) is always expressed as positive values.

\section{Initial steady-state pressures}

Post-installation and steady-state pore water pressure and total horizontal stress measurements before the tunnel construction (period 1) are discussed by Wan \& Standing (2014b) and Wan (2014), while this paper concentrates on the short-term responses observed during periods 2 and 4 . The profiles of steady-state pore water pressure before the arrival of TBM1 as reported in Wan \& Standing (2014b) are shown in Fig. 3. Note that before the tunnel construction, all piezometers were expected to measure greenfield ground pore water pressures except for HP34, which is located $5 \mathrm{~m}$ from the existing Central Line westbound tunnel. The greenfield measurements from HP32 (Fig. 3(a)) indicate a slightly under-drained steady-state piezometric profile within the LCF, while it is evident from the measurements from HP34 (Fig. 3(b)) that the steady-state pore water pressure near the existing Central Line tunnels is reduced, indicating that these tunnels, with cast-iron segmental linings, drain the surrounding ground. It should be noted that the profile for HP33 would also be expected to register slight under-drainage, but is close to hydrostatic because of suspected connectivity between the lower devices, as explained by Wan \& Standing (2014b).

The total horizontal stresses measured by the spade cells (without correction of any factor of undrained shear strength) before the tunnel construction are given in Table 2 (note that the undrained shear strength determined from unconsolidated undrained triaxial tests on $100 \mathrm{~mm}$ dia. samples from boreholes in Hyde Park ranges from $150 \mathrm{kPa}$ to $400 \mathrm{kPa}$ at the level of the Crossrail tunnels (see Fig. 9 in Wan \& Standing (2014a)). Using these uncorrected measured total horizontal stresses in conjunction with the known overburden stress and the measured pore water pressure at the depth of the spade cells, the at-rest lateral earth pressure coefficients $\left(K_{0}\right)$ can be deduced and are also presented in Table 2. With the exception of the spade cell HP35, which measured unrealistically low total horizontal stress, the derived in situ $K_{0}$ values at the depths of spade cells HP36, HP37 and HP39 fall within a range from 1.9 to $2 \cdot 4$. Taking into account the likely over-read of the in situ stresses by spade cells, it is considered that these $K_{0}$ values are reasonable. Nearby, at Paddington, $K_{0}$ values of up to about 1.7 derived from self-boring pressuremeter measurements and independent suction measurements of undisturbed samples near the depth of the Crossrail tunnel axis level - that is, near the base of London Clay unit B (GCG, 2009) - corroborate the measured initial values of total horizontal stress from the spade cells. Typically, the design $K_{0}$ value of London Clay in central London, considering the historical erosion of top clays and subsequent reloading of superficial deposit, ranges from 1.0 to $1 \cdot 5$ (Burland et al., 1979).

Table 1. Average face pressure and tail grout pressure when the cutter-head or shield tail of both TBMs passed the instrument boreholes

\begin{tabular}{l|c|c|c|c}
\hline \multirow{2}{*}{ Instrument borehole } & \multicolumn{2}{|c|}{ TBM1 } & \multicolumn{2}{c}{ TBM2 } \\
\cline { 2 - 5 } & Face pressure: kPa & Tail grout pressure: kPa & Face pressure: kPa & Tail grout pressure: kPa \\
\hline \multirow{2}{*}{ HP34 } & 190 & 120 & 200 & 150 \\
HP32, HP33 & 180 & 120 & 210 & 80 \\
HP35, HP36, HP37, HP39 & 195 & 80 & 200 & 70 \\
\hline
\end{tabular}

Table 2. Steady-state pore water pressures and total horizontal stress (uncorrected by over-read factor) measured by combined spade cells, and estimated $K_{0}$ before tunnel construction

\begin{tabular}{l|c|c|c|c}
\hline $\begin{array}{l}\text { Instrument } \\
\text { borehole }\end{array}$ & $\begin{array}{c}\text { Depth of spade } \\
\text { mid-point: mbgl }\end{array}$ & $\begin{array}{c}\text { Pore water } \\
\text { pressure: kPa }\end{array}$ & $\begin{array}{c}\text { Total horizontal } \\
\text { stress: kPa }\end{array}$ & $\begin{array}{c}\text { Estimated at-rest lateral earth pressure } \\
\text { coefficient, } K_{0}\end{array}$ \\
\hline HP35 & $34 \cdot 3$ & 263 & 267 & N/A \\
HP36 & $35 \cdot 0$ & 266 & 1077 & $2 \cdot 1$ \\
HP37 & $34 \cdot 9$ & 273 & 1201 & $1 \cdot 9$ \\
HP39 & $29 \cdot 2$ & 234 & 838 & $1 \cdot 9$ \\
\hline
\end{tabular}

N/A, not applicable. 
Measurement frequency during tunnel construction (passages of TBM1 and TBM2)

For the multi-level VW piezometers and combined spade cells, during periods 2 and 4, hourly readings were taken and recorded automatically by data-loggers within each borehole headworks, except spade cells HP36 and HP37 where readings were taken manually using a hand-held VW readout unit three to four times a day owing to faulty data-loggers.

In the next sections the measurement results are presented in terms of either time or the distance, $x_{\mathrm{f}}$, of the EPBM cutter-head relative to the monitoring line. The progression of both TBM1 and TBM2 with time is given by Wan et al. (2017a: Fig. 6).

\section{MEASURED IMMEDIATE RESPONSES TO THE WESTBOUND TUNNEL CONSTRUCTION (TBM1, PERIOD 2)}

In this section the responses of the three multi-level piezometers are discussed individually (for period 2), starting with HP32 and HP33, which are located in ground where a more greenfield response would be expected. HP34, located close to the existing Central Line tunnels is covered next. The combined total stress transducerpiezometer spade cells (HP35, HP36, HP37 and HP39), clustered around the eastbound tunnel, are then covered collectively.

\section{Response of HP32 piezometers (TBM1, period 2)}

Changes in pore water pressure, $\Delta u$, measured by the VW piezometer sensors in HP32 as TBM1 passed are presented in Fig. 5(a). In plan HP32 is about $10 \cdot 8 \mathrm{~m}$ from the TBM1 centre-line, or one tunnel diameter from the extrados of the excavation. No measurement results are shown for the sensor at $z=-24.5 \mathrm{~m}$ as it was faulty. Pore water pressures started to change at all elevations when $x_{\mathrm{f}}=-30 \mathrm{~m}$. At about $25 \mathrm{~m}$ in front of the HP32 piezometers $\left(x_{\mathrm{f}}=-25 \mathrm{~m}\right)$, TBM1 stopped advancing for about $31 \mathrm{~h}$ because of problems with the spoil muck-away system. During this time the pore water pressures

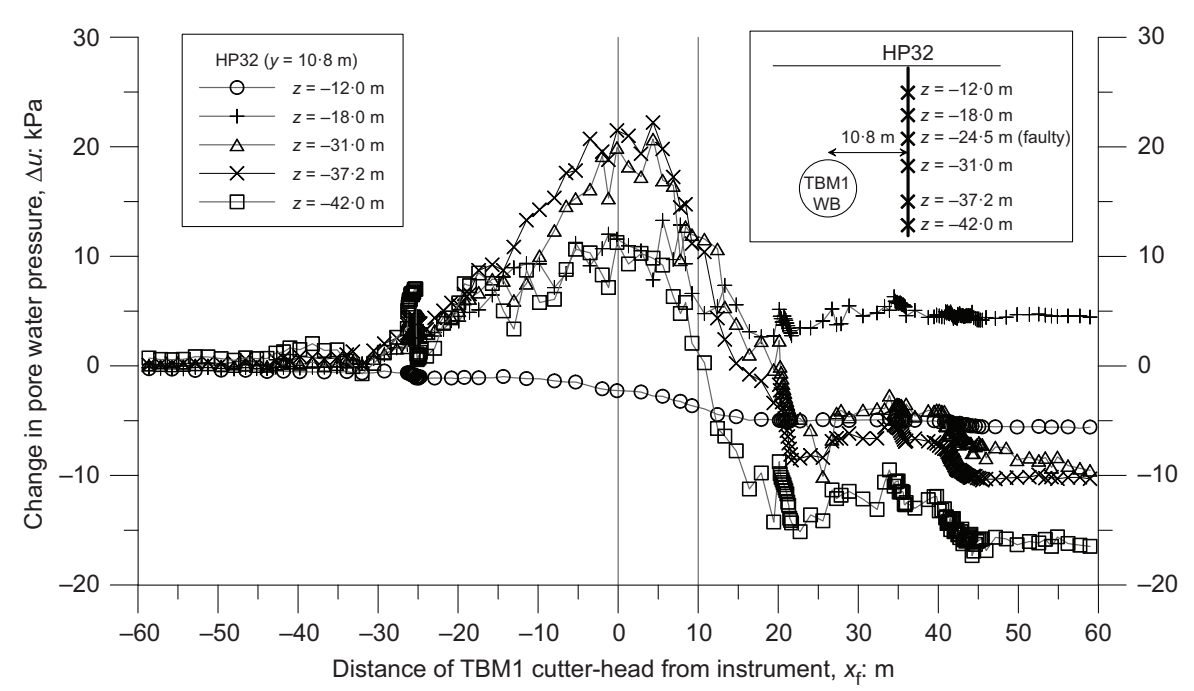

(a)

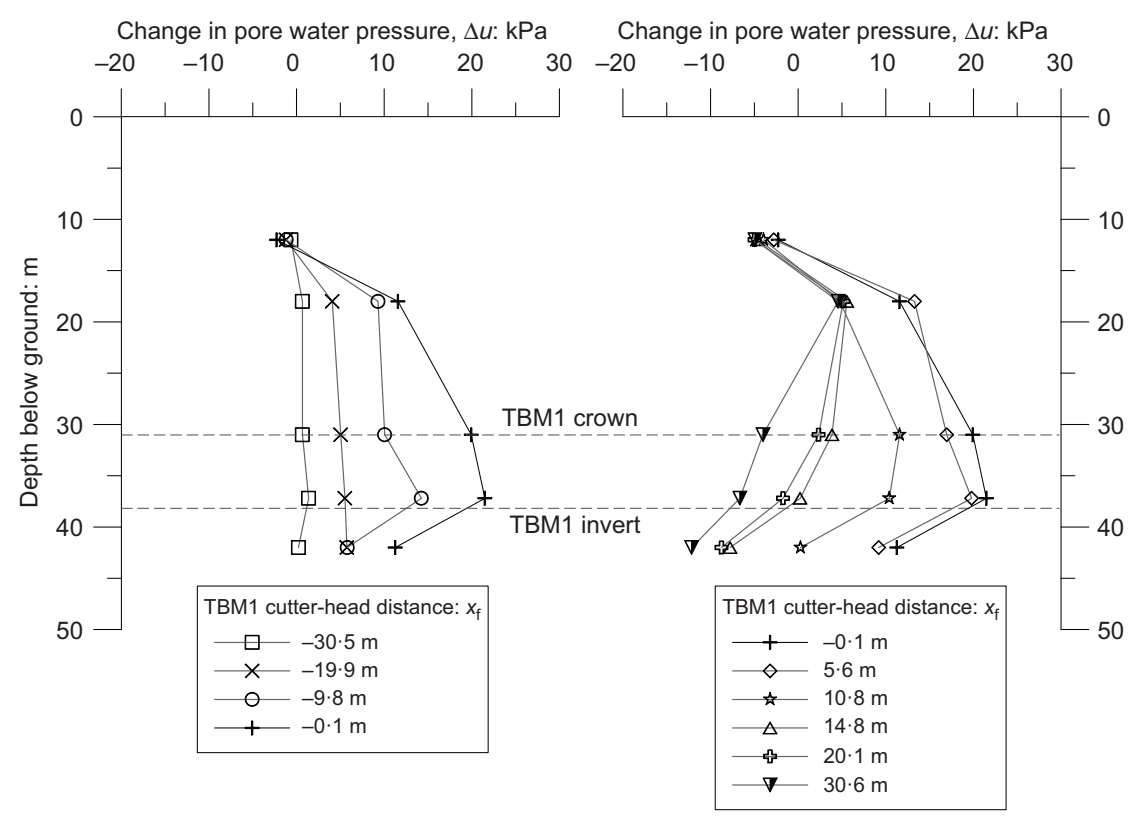

(b)

(c)

Fig. 5. Change in pore water pressure measured in piezometer HP32 in response to westbound construction (period 2): (a) variation with TBM1 cutter-head distance; (b) depth profiles when the TBM1 cutter-head was approaching the instrument; (c) depth profile when TBM1 cutter-head was leaving the instrument 
measured within HP32 over the depth of the TBM $(-31 \mathrm{~m}$ $<z<-42 \mathrm{~m}$ ) fluctuated by a small degree: within about $\pm 3 \mathrm{kPa}$. This incident did not cause significant settlement measured by the surface settlement points (Wan et al., 2017a: Fig. 8(a)) or subsurface rod extensometers (Wan et al., 2017b: Fig. 3).

The pore water pressures at the measurement depths, except that furthest from the TBM at $z=-12 \mathrm{~m}$, increased as the TBM cutter-head approached, peaking when it was about $5 \mathrm{~m}$ beyond the instruments $\left(x_{\mathrm{f}}=5 \mathrm{~m}\right)$. A maximum pore water pressure change of about $+22 \mathrm{kPa}$ was measured at the elevations near TBM1 crown and invert levels $(z=-31 \cdot 0 \mathrm{~m}$ and $z=-37 \cdot 2 \mathrm{~m})$ which are equidistant from the axis of TBM1. The fact that these piezometers measured pore water pressure increases of a similar magnitude suggests that they are measuring an essentially undrained response to the TBM cutter-head approaching, despite the fact that the lower device is just within the more permeable A3ii sub-division of the LCF (see Fig. 2). Since the TBM face pressure (about $180 \mathrm{kPa}$ on average) was lower than the overburden pressure at the tunnel axis level (about $650 \mathrm{kPa}$ ), it is believed that the pore water pressure increase in front of the TBM cutter-head was caused by ground arching in front of and around the TBM shield face (discussed in the section entitled 'Mechanisms of EPBM tunnelling-induced pore water pressure changes and ground arching').

As the TBM advanced and passed beyond the instruments, the pore water pressures at all elevations decreased as a result of the predominantly undrained unloading caused by the excavation until the TBM1 cutter-head was at a distance of about $x_{\mathrm{f}}=25 \mathrm{~m}$. The magnitude of the final change of the pore water pressure depends on the balance between the loading and unloading effects, the distance from the TBM, and also the permeability of the London Clay at the point of measurement. The undrained shearing of the overconsolidated clay would also generate additional negative excess pore water pressure. It appears that the shallowest sensor at $z=-12 \mathrm{~m}$ was too far from TBM1 to be affected by the effect of the approaching cutter-head, but measured a slight decrease in pore water pressure due to the effect of ground unloading. The TBM1 tail leaving the instruments does not seem to have any significant effect on the pore water pressure (near $x_{\mathrm{f}}=10 \mathrm{~m}$ ) in HP32, although a very minor effect is noticed for the two sensors near the TBM crown and invert levels. By the time TBM1 is $60 \mathrm{~m}$ from HP32, all sensors have essentially stabilised, with the two shallowest ones being within $\pm 5 \mathrm{kPa}$ of their original values and the others with net negative changes (the largest being $\Delta u=-16 \mathrm{kPa}$ at $z=-42 \cdot 0 \mathrm{~m})$.

Before stabilising, there are two points in time (at $x_{\mathrm{f}}$ distances of about $+20 \mathrm{~m}$ and $+40 \mathrm{~m}$ ) when the sensors closer to the TBM appear to indicate marked, but small $(<5 \mathrm{kPa})$, reductions in pore water pressure, the magnitudes of which decrease with increasing distance of the TBM from the sensors. The data points, which represent hourly readings, are closely clustered at these $x_{\mathrm{f}}$ distances and so coincide with times at which the TBM slowed down or was not advancing. The reason for the reductions is not known. Similar responses are also observed when the TBM slows down in some of the later plots.

Many of the observations described above are evident from vertical profiles of pore water pressure changes measured in HP32, which are plotted separately as TBM1 was approaching (Fig. 5(b)) and leaving HP32 (Fig. 5(c)). It is clear from these figures that the increase in pore water pressure in response to the TBM1 face approaching and then the subsequent reduction due to ground unloading was greatest at the TBM horizons.

\section{Response of HP33 piezometers (TBM1, period 2)}

Changes in pore water pressure measured by the VW piezometers in HP33 during period 2 are presented in terms of cutter-head distance in Fig. 6(a). HP33 is at a greater distance away from TBM1 than HP32 (about $16.0 \mathrm{~m}$ in plan from its centre-line) and therefore the overall response was of smaller magnitude. As with HP32, pore water pressures also started to change when $x_{\mathrm{f}}=-30 \mathrm{~m}$. The effect of the TBM1 stopping at $x_{\mathrm{f}}=-25 \mathrm{~m}$ was not as obvious as measured in HP32 as HP33 was further from the tunnel. As the TBM1 cutter-head approached and passed beyond HP33, pore water pressure at the deeper four elevations gradually increased with a maximum $\Delta u$ of about $+15 \mathrm{kPa}$ measured at $z=-29 \cdot 0 \mathrm{~m}$ near the TBM1 crown level. Only small changes $(\Delta u<10 \mathrm{kPa})$ were measured at the two shallowest sensor elevations $(\Delta u \sim 0$, at $z=-9 \mathrm{~m})$. There was no discernible pore water pressure response above the TBM1 crown level to the ground unloading (i.e. pressure drop), as the shield tail passed HP33 (around $x_{\mathrm{f}}=10 \mathrm{~m}$ ), except a small reduction at $z=-14 \mathrm{~m}$. The response of the piezometer at this depth is slightly erratic at earlier TBM positions (e.g. $x_{\mathrm{f}}=-18 \mathrm{~m}$ ) and so the output from it could be erroneous, especially given the piezometer responses above and below it (at $z=-9$ and $-17 \mathrm{~m}$ ). Therefore, overall the effect of stress relief or shearing due to excavation was not registered by the piezometers within HP33.

Similar to the observation for HP32 (Fig. 5(a)), there were marked reductions in pore water pressure measured by the HP33 sensors at $x_{\mathrm{f}}=+20 \mathrm{~m}$, when the TBM advance slowed down, but their magnitudes are even smaller than those measured in HP32.

Profiles of $\Delta u$ with depth when TBM1 was approaching and passing beyond HP33 are shown in Figs 6(b) and 6(c), respectively, and reflect many of the observations made above (especially regarding the piezometer at $z=-14 \mathrm{~m}$ : if the data from this device were omitted the profiles would be far more uniform). As discussed in Wan \& Standing (2014b), the lowest three piezometers within HP33 were found during the pre-construction monitoring to be interconnected after installation. Despite this, independent immediate pore water pressure changes still seem to have been measured reliably by these three lowest sensors in response to the rapid loading and unloading during tunnel construction, with the pressure increase decreasing with distance from the tunnel crown.

\section{Response of HP34 piezometers (TBM1, period 2)}

Multilevel piezometer borehole HP34 is $5 \mathrm{~m}$ in plan from the extrados of the westbound Central Line tunnel and was located directly above TBM1 when it passed, with the deepest sensor at $z=-29 \cdot 0 \mathrm{~m}$, just $2 \mathrm{~m}$ above its crown. Consequently the measured pore water pressures might have been expected to be more pronounced as TBM1 approached and passed.

It can be seen from the measured values of $\Delta u$ presented in Fig. 7(a) that this was not so (results from the piezometer at $z=-26 \mathrm{~m}$ are not shown as it was faulty). Increases in pore water pressure were less than $5 \mathrm{kPa}$ as TBM1 approached HP34, compared with an increase of up to $22 \mathrm{kPa}$ and $11 \mathrm{kPa}$ measured at HP32 and HP33, respectively, which were more than $10 \mathrm{~m}$ horizontally from the TBM1 centreline. The reduced increase in $\Delta u$ probably occurs because of the close proximity of the adjacent existing Central Line tunnels, which would have affected the ground loading/unloading pattern and the development of any ground arching in front of the advancing TBM cutter-head.

Pore water pressures started to decrease when the cutterhead was about $7 \mathrm{~m}$, or about one tunnel diameter, in front of 


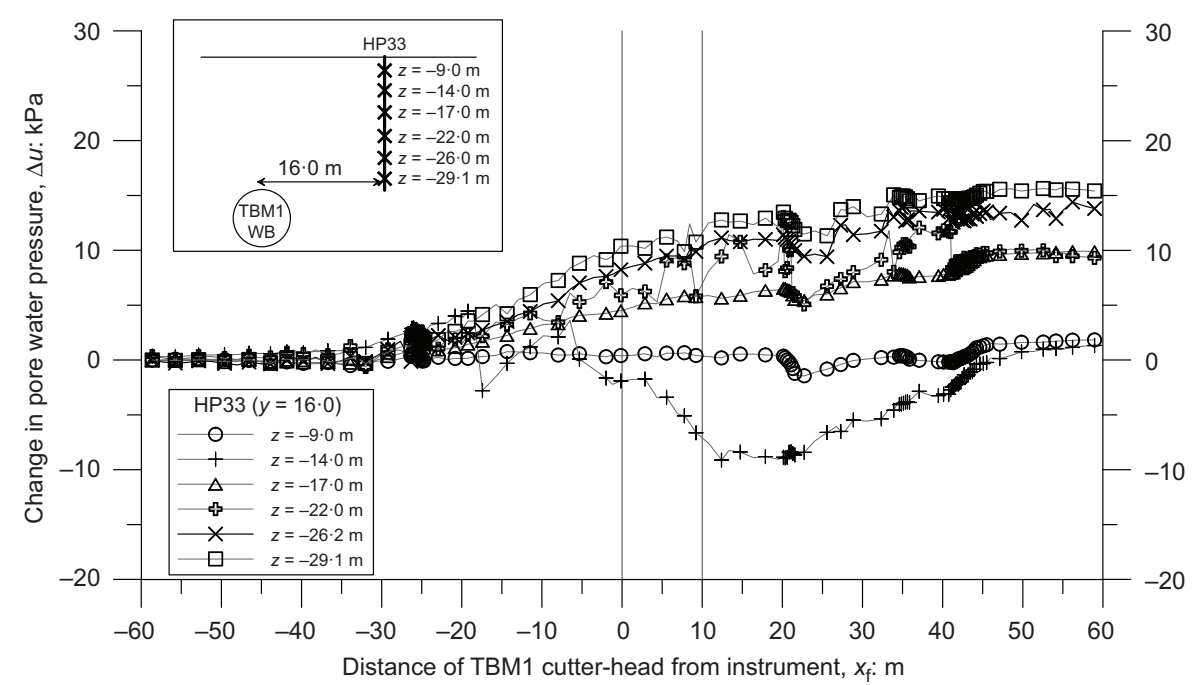

(a)

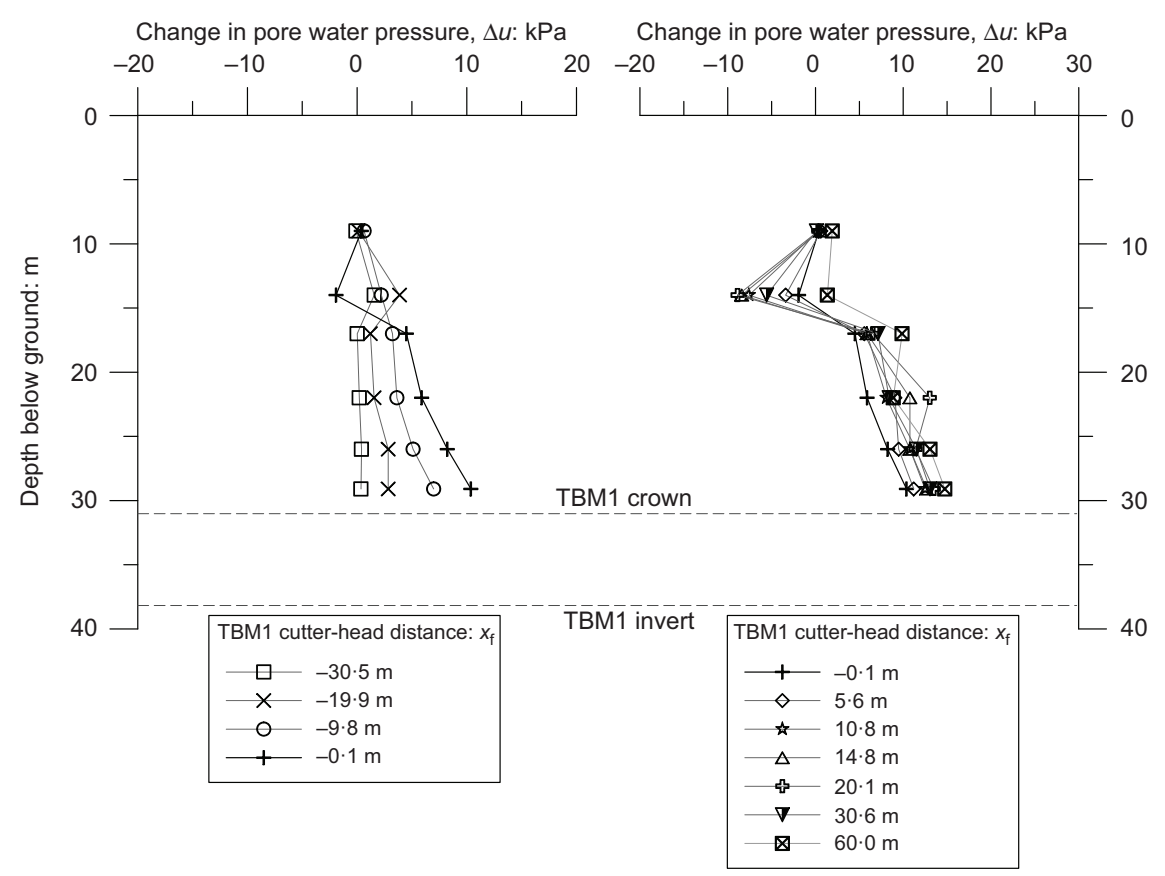

(b)

(c)

Fig. 6. Change in pore water pressure measured in piezometer HP33 in response to westbound construction (period 2): (a) variation with TBM1 cutter-head distance; (b) depth profiles when the TBM1 cutter-head was approaching the instrument; (c) depth profile when TBM1 cutter-head was leaving the instrument

HP34 $\left(x_{\mathrm{f}}=-7 \mathrm{~m}\right)$. The greatest recorded change was at $z=-29 \mathrm{~m}$, above which values decreased with increasing elevation above the TBM1 crown. Pressures continued to decrease until about $x_{\mathrm{f}}=4 \mathrm{~m}$ as negative excess pore water pressures were generated as a result of unloading around the front section of the shield body (i.e. soil closing into the annular void created by the tapering shield) and possibly also shearing of the overconsolidated clay. Subsequently, at elevations closer to the TBM1 crown (i.e. $z=-22 \mathrm{~m}$ and $-29 \mathrm{~m}$ ), pore water pressures rebounded by up to $35 \mathrm{kPa}$. This could be a consequence of the tail grout pressure compressing the ground (even though the main effect of the grouting would be expected directly behind the rear of the shield) and correlates exactly with what was observed from the response of the extensometers directly above TBM1 as reported by Wan et al. (2017b: Fig. 3(b)). (Note that the comparison made relates to extensometer HP20, which is about $38 \mathrm{~m}$ from HP34. However, the response of extensometer HP26, directly adjacent to HP34, was very similar but with a less marked rebound (this response was not presented in the Wan et al. (2017b) paper but was in the thesis by Wan (2014)).) Ground heave from tail grouting occurred at about $x_{\mathrm{f}}=7 \mathrm{~m}$, in advance of the back of the shield passing beneath the measuring point, followed by a rapid settlement. Another explanation for this increase in $\Delta u$ (rebound) before the back of the shield passes beneath HP34 can again be provided by a mechanism of ground arching. Ground arches would form around locations where ground losses are greatest and the ground has softened or 'yielded' (i.e. at the shield tail where tail void closure starts to occur before the grouting comes into effect). The ground arching would compress the ground in front of and behind the shield tail, leading to increases in pore water pressure (discussed further in the section entitled 'Mechanisms of EPBM tunnelling-induced pore water pressure changes and ground arching').

Similarly, in terms of pore water pressure changes, following the rebound, $\Delta u$ values dropped rapidly at the 


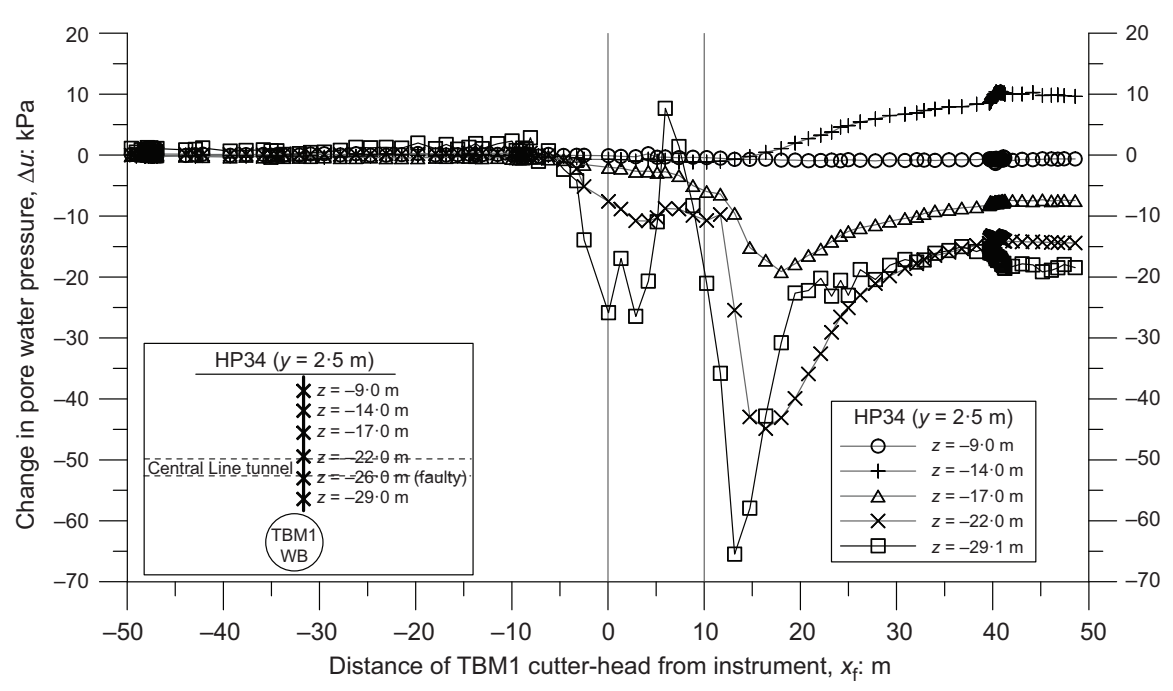

(a)

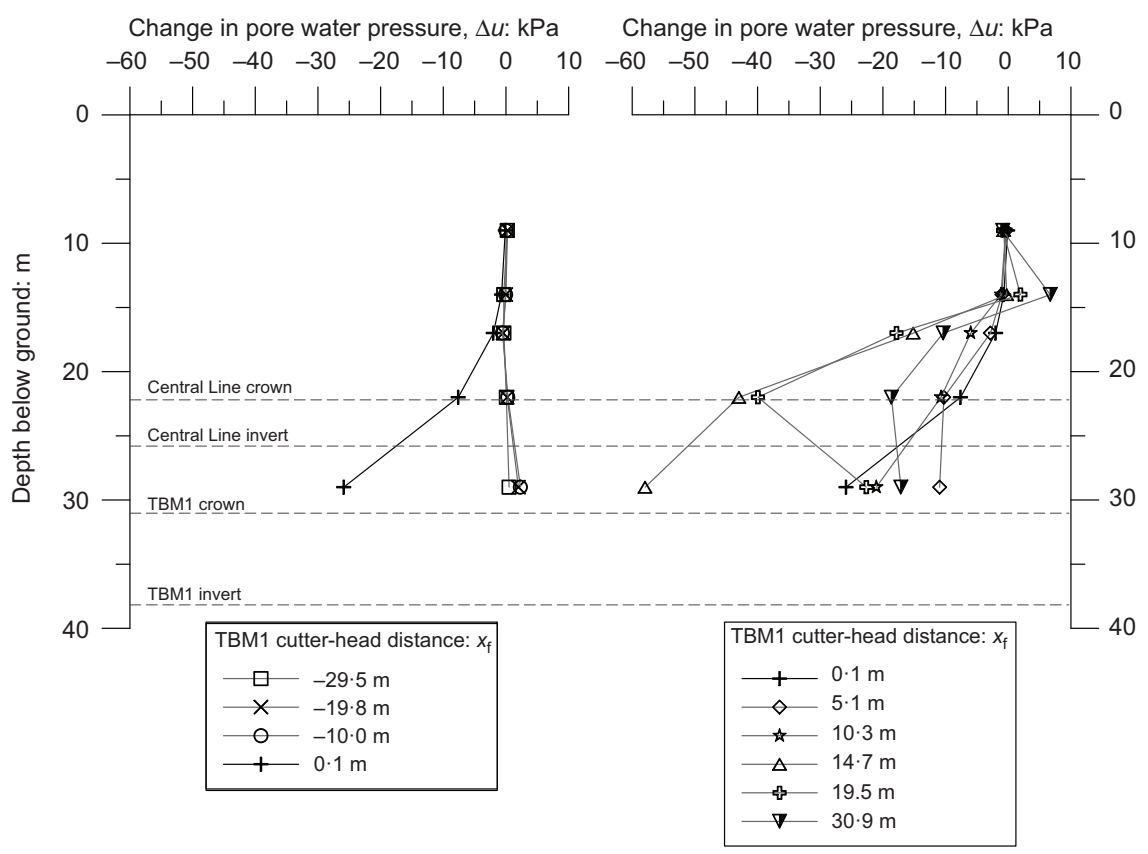

(b)

(c)

Fig. 7. Change in pore water pressure measured in piezometer HP34 in response to westbound construction (period 2): (a) variation with TBM1 cutter-head distance; (b) depth profiles when the TBM1 cutter-head was approaching the instrument; (c) depth profile when TBM1 cutter-head was leaving the instrument

deeper elevations as the rear of TBM1 passed beyond HP34 (Fig. 7(a) from $x_{\mathrm{f}}=7 \mathrm{~m}$ onwards). This reduction in $\Delta u$ occurred as the shield was advanced and the ground lost the support of the shield body, leading to further ground loss into the gap between the tail-skin and the extrados of the newly erected tunnel linings (tail void closure). A maximum reduction of pore water pressure of about $-75 \mathrm{kPa}$ was measured at $z=-29 \mathrm{~m}$ when $x_{\mathrm{f}}=13 \mathrm{~m}$. A similar response in terms of displacement was observed (Wan et al., 2017b: Fig. 3(b)). It is evident that, for the ground near the shield tail $\left(x_{\mathrm{f}}=10 \mathrm{~m}\right)$ the effect of tail void closure (stress relief) significantly outweighs the effect of tail grout pressure (compressing the ground). Soon afterwards the pore water pressures began to recover as the newly erected tunnel linings, in conjunction with tail grout setting and becoming stiffer, started to support the annulus between their extrados and the ground and also because of the development of ground arching across the rear of the shield. For the three operational sensors above the TBM1 crown $(-29 \mathrm{~m}<z<-17 \mathrm{~m})$, the final pore water pressures were smaller than those prior to the construction.

Profiles of pore water pressure changes with depth for the periods when TBM1 approached and passed beyond HP34 are shown in Figs 7(b) and 7(c).

\section{Response of spade cells HP35, HP36, HP37 and HP39 (TBM1, period 2)}

As can be seen from Fig. 1, the spade cells are all very close to the eastbound tunnel alignment (therefore at some distance away from TBM1). Changes in pore water pressures, $\Delta u$, and total horizontal stresses, $\Delta \sigma_{\mathrm{h}}$, measured by the spade cells in response to the westbound construction are shown in Fig. 8. Spade cell HP39 was located at the same $y-z$ position as the deepest piezometer of HP33: its pore water pressure response, as shown in Fig. 8(a), has a similar pattern, with an increase in pressure (cf. Fig. 6(a)), but of slightly greater magnitude than the deepest piezometer 


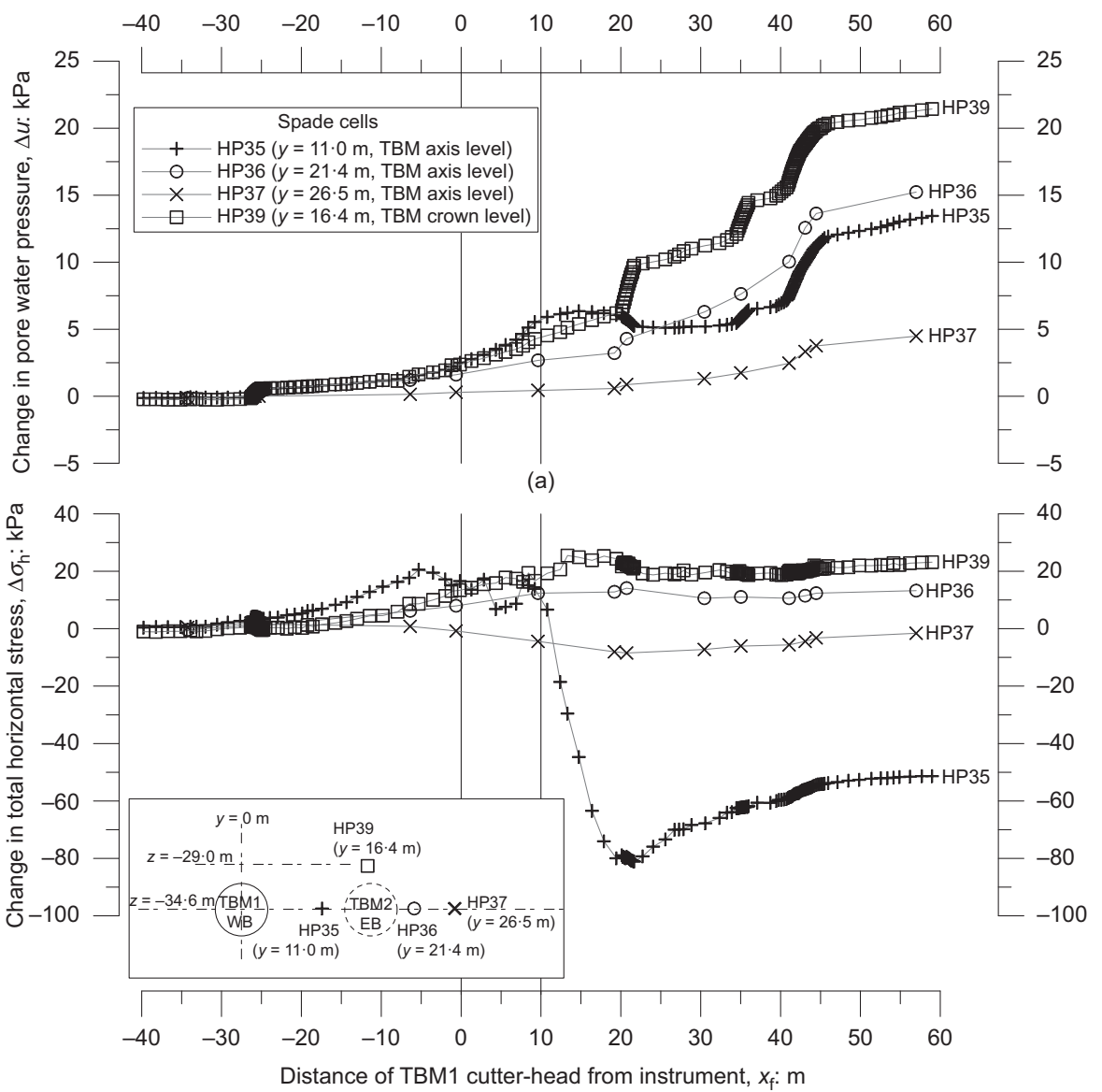

(b)

Fig. 8. Change in (a) pore water pressure and (b) total horizontal stress measured in spade cells HP35, HP36, HP37 and HP39 in response to westbound construction (period 2)

in HP33 as TBM1 progressed. A potential reason for the differences in magnitude is that the piezometer within the spade cell responds more simultaneously with total stress changes as it is in direct contact with the ground (from pushing in the device) compared with the multi-level piezometer installed within a grout column. The other three spade cells HP35, HP36 and HP37, located at the elevation of the TBM axis, also exhibited similar pore water pressure responses but of smaller magnitude. Spade cell HP35, closest to TBM1 (11 m from its centre-line or about one diameter from the tunnel extrados), measured a slight drop of pore water pressure at $x_{\mathrm{f}} \approx 20 \mathrm{~m}$, compared with the other three devices which showed a small increase.

Total horizontal stress changes, $\Delta \sigma_{\mathrm{h}}$, transverse to the axis of the tunnel are shown in Fig. 8(b). Those measured by HP35 were the largest in magnitude, it being the closest spade cell to TBM1 (although still $11 \mathrm{~m}$ from its axis). At this location, the total stress initially increased by $20 \mathrm{kPa}$ in response to the approaching cutter-head (probably associated with ground arching in front of the cutter-head). The unloading effect in the vicinity of the rear of the shield as it passed is evident as a rapid, large drop in total stress (for $x_{\mathrm{f}}>10 \mathrm{~m}$ ). A maximum decrease of about $-80 \mathrm{kPa}$ was measured at $x_{\mathrm{f}}=20 \mathrm{~m}$, before $\sigma_{\mathrm{h}}$ started recovering. The net total stress reduction was measured to be about $-50 \mathrm{kPa}$, indicating the overall effect of the tunnel excavation and the newly erected tunnel lining supporting the ground. Additionally, as HP35 is located within the very silty B1 sub-division, some pore water pressure dissipation might occur in the short term.
At the other spade cells (HP36, HP37 and HP39) further away from TBM1, initial increases in total stresses were smaller (up to $+10 \mathrm{kPa}$ ) as TBM1 advanced and passed, followed by negligible subsequent drops and rises after the initial increases (less than $\pm 5 \mathrm{kPa}$ ) compared with the response observed for HP35.

Further interpretation. It is instructive to compare the total stress change responses with corresponding displacements measured using rod extensometers (vertical) and inclinometers (horizontal) as presented and discussed by Wan et al. (2017b). In terms of vertical displacements at axis level, the maximum magnitude was less than $4 \mathrm{~mm}$ downwards at extensometer HP22 (Wan et al., 2017b: Fig. 4), which is closer than spade cell HP35 from the TBM1 axis $(8 \cdot 1 \mathrm{~m}$ compared to $11.0 \mathrm{~m}$ ), although this sense of displacement might not have much influence on the spade cells orientated to measure horizontal stresses. In terms of horizontal displacements, no face pressure-induced outward movement was observed, even close to the tunnel (see details given of horizontal displacements at closest inclinometer borehole HP6, as shown in Fig. 10(a) in the paper by Wan et al. (2017b)) while $\Delta \sigma_{\mathrm{h}}$ increased (by up to about $20 \mathrm{kPa}$ ) in HP35 as TBM1 approached the instrument. The subsequent reduction in $\Delta \sigma_{\mathrm{h}}$ within HP35 correlates with the horizontal displacements in towards the tunnel observed from inclinometer HP7 (at the same, closer, offset as extensometer HP22) as TBM1 progressed beyond it (Wan et al., 2017b: Fig. 11). At this offset, no reversal of displacements was observed from tail grouting as was observed for inclinometer 
HP6 (Wan et al., 2017b: Fig. 10(b)). Qualitatively the measured displacements and total horizontal stress changes correlate with each other.

\section{MEASURED IMMEDIATE RESPONSE TO EASTBOUND TUNNEL CONSTRUCTION (TBM2, PERIOD 4)}

Piezometer and spade cell measurements are presented and discussed in this section in the same order as previously. Generally responses were much more marked for the eastbound tunnel construction (TBM2) as the devices (except HP34) were much closer to this excavation and trends in changes were broadly similar.

\section{Response of HP32 piezometers (TBM2, period 4)}

HP32 lies very close to the tunnel construction, being about $1.5 \mathrm{~m}$ (less than half of a tunnel radius) horizontally from the TBM2 extrados, resulting in a much greater pore water pressure response than that from the westbound tunnel construction. Changes in $\Delta u$ measured by the five operational piezometers in HP32 as TBM2 passed are shown in Fig. 9(a), where it can be seen that $\Delta u$ increased at all elevations, except the shallowest one, when TBM2 was at $x_{\mathrm{f}}=-40 \mathrm{~m}$, rising rapidly by $x_{\mathrm{f}}=-15 \mathrm{~m}$. Peak increases were measured within $-10 \mathrm{~m}<x_{\mathrm{f}}<-3 \mathrm{~m}$, depending on the individual piezometer elevations. A maximum change of about $+50 \mathrm{kPa}$ was measured at elevations near the TBM2 crown and invert levels $(z=-31.0 \mathrm{~m}$ and $-37.2 \mathrm{~m})$ in response to the approaching TBM2 cutter-head and the development of ground arching. Pore water pressures then dropped rapidly by up to $130 \mathrm{kPa}$ near $x_{\mathrm{f}}=0 \mathrm{~m}$, from the unloading and shearing associated with the excavation and advance of the shield. These $\Delta u$ values suggest that conditions were essentially undrained. The effect of tail grouting (average pressure of about $80 \mathrm{kPa}$ ) and the development of ground arching is evident from pore water

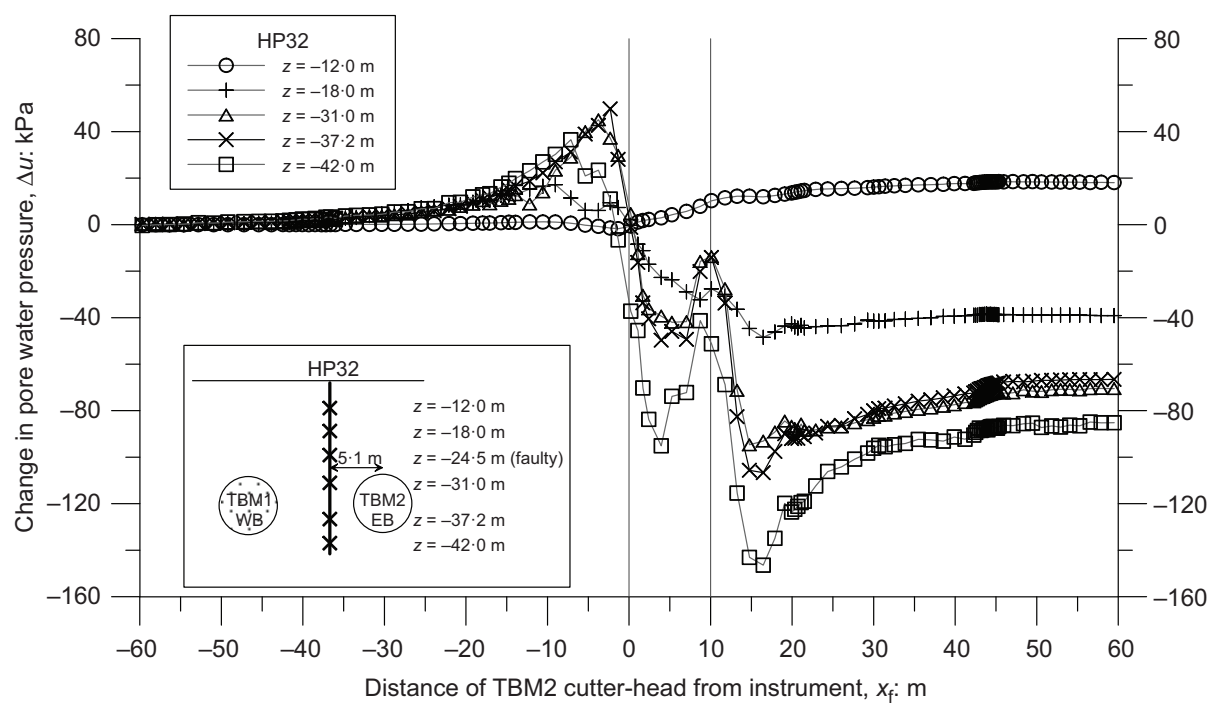

(a)

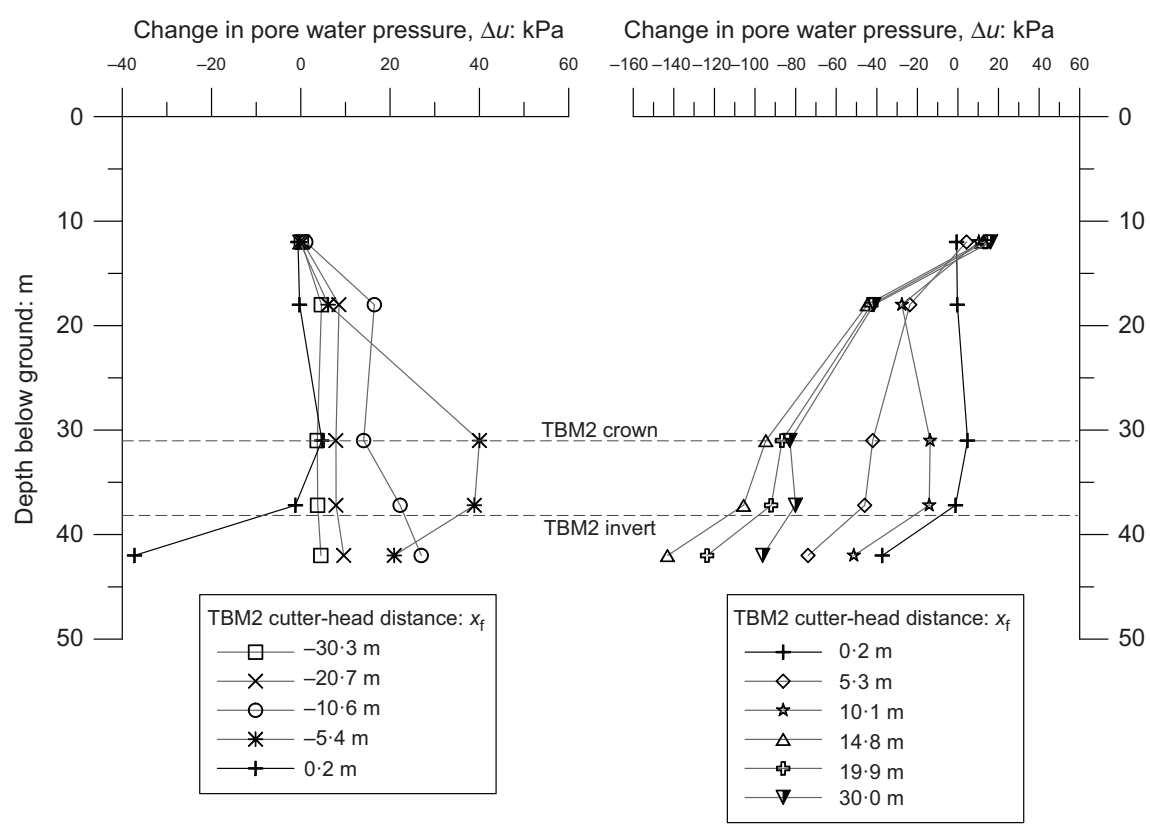

(b)

(c)

Fig. 9. Change in pore water pressure measured in piezometer HP32 in response to eastbound construction (period 4): (a) variation with TBM2 cutter-head distance; (b) depth profiles when the TBM2 cutter-head was approaching the instrument; (c) depth profile when TBM2 cutter-head was leaving the instrument 
pressures starting to recover between $5 \mathrm{~m}<x_{\mathrm{f}}<10 \mathrm{~m}$ with rebounds ranging from $30 \mathrm{kPa}$ to $50 \mathrm{kPa}$ at elevations close to TBM2 (as noted for TBM1, these increases occur well in advance of the tail skin reaching the monitoring position). This correlates very well with the ground being temporarily pushed outwards by the tail grout in advance of the TBM2 tail skin as measured by inclinometer HP9, which was at a similar offset distance to the TBM2 axis but on the other side (Wan et al., 2017b: Figs 12 and 13).

As the shield tail passed beyond HP32, $x_{\mathrm{f}}>10 \mathrm{~m}$, there was a second rapid reduction as a result of further unloading (tail void closure). The maximum net reduction of pore water pressure was about $-150 \mathrm{kPa}$ measured below the tunnel invert at $z=-42 \mathrm{~m}$ when $x_{\mathrm{f}} \approx 15 \mathrm{~m}$. Pore water pressures then started to recover by different degrees from the tail grout setting and becoming stiffer as TBM 2 advanced further.

The depth profiles of the change in pore water pressures measured in HP32 as TBM2 was approaching and leaving are shown in Figs 9(b) and 9(c), respectively, and reflect the trends described above. Being nearest to the TBM location, the sensors at $z=-31 \mathrm{~m}$ and $-37.2 \mathrm{~m}$ measured the greatest pore water pressure increase when the TBM cutter-head was approaching (when $x_{\mathrm{f}}=-5.4 \mathrm{~m}$ ). As TBM2 passed beyond HP32, the piezometer at $z=-42 \mathrm{~m}$, being the deepest one, experienced the largest unloading as the ground above it was excavated and hence measured the greatest pore water pressure reduction.

\section{Response of HP33 piezometers (TBM2, period 4)}

The $\Delta u$ values measured by the piezometers in HP33 as TBM2 passed beneath them are presented in Fig. 10(a). The measured responses to the eastbound construction show a very similar pattern to those of HP34 in response to the westbound construction (see Fig. 7(a)), but are generally of larger magnitude. In particular, the pressure increase

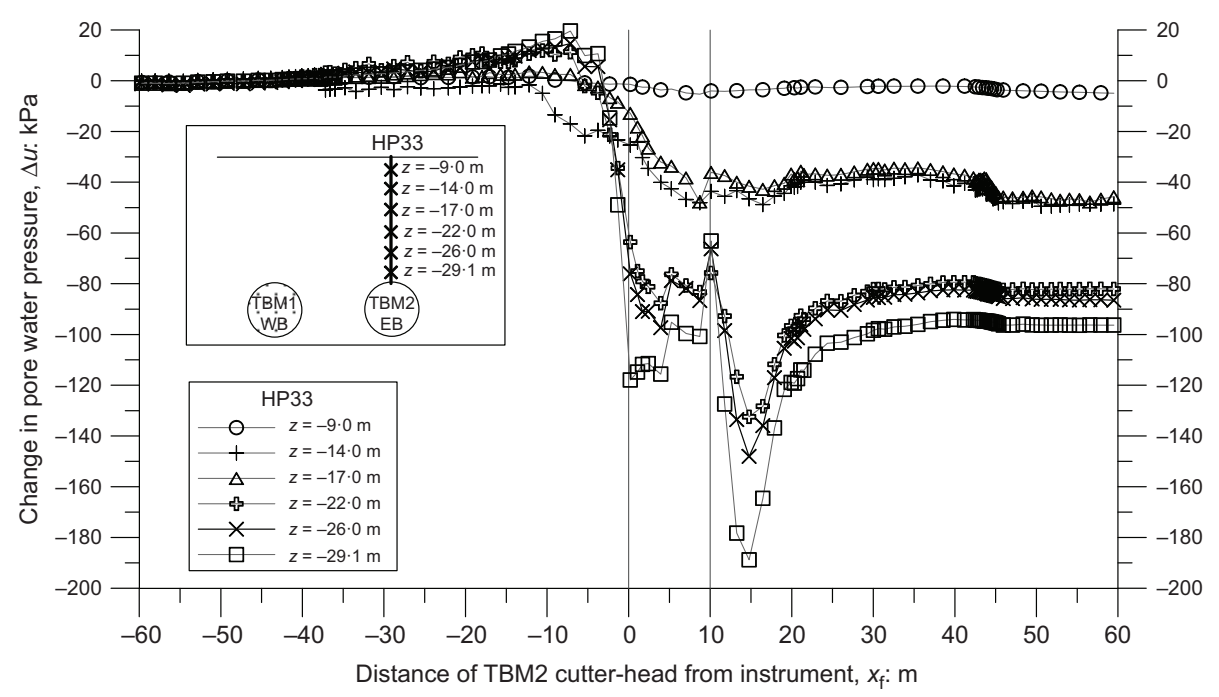

(a)

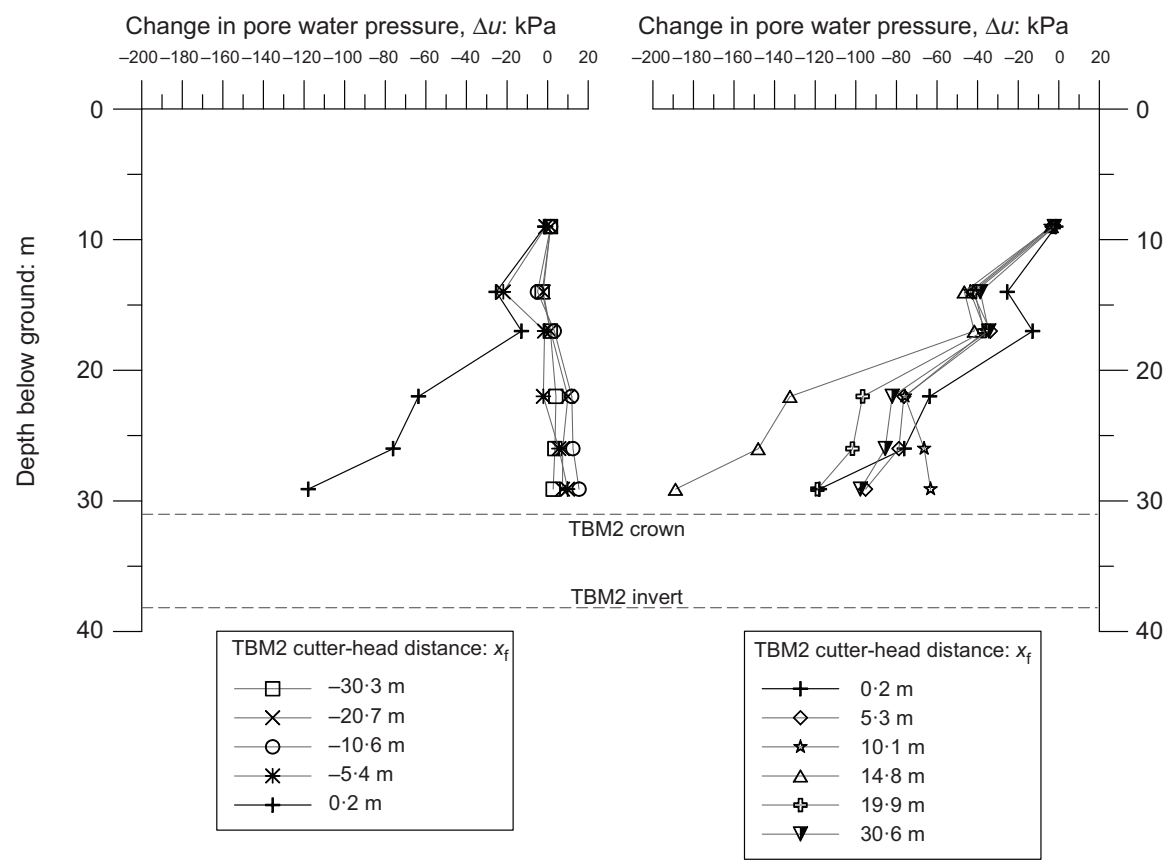

(b)

(c)

Fig. 10. Change in pore water pressure measured in piezometer HP33 in response to eastbound construction (period 4): (a) variation with TBM2 cutter-head distance; (b) depth profiles when the TBM2 cutter-head was approaching the instrument; (c) depth profile when TBM2 cutter-head was leaving the instrument 
measured by HP33 ahead of the cutter-head was more pronounced, probably because ground arching in front of the cutter-head could develop freely without any interference from the existing Central Line tunnels. Pore water pressures increased (up to $+20 \mathrm{kPa}$ ) as the TBM2 cutter-head approached, followed by: a rapid drop of pore water pressure near $x_{\mathrm{f}}=0 \mathrm{~m}$; subsequent rebound between $5 \mathrm{~m}<$ $x_{\mathrm{f}}<10 \mathrm{~m}$; a further drop between $10 \mathrm{~m}<x_{\mathrm{f}}<15 \mathrm{~m}$; and subsequent partial recovery. The greatest net reduction of pore water pressure was about $-190 \mathrm{kPa}$ at $z=-29 \mathrm{~m}$ when $x_{\mathrm{f}}=15 \mathrm{~m}$. Profiles of $\Delta u$ with depth as TBM2 was approaching and leaving are presented in Figs 10(b) and 10(c), respectively. The deepest piezometer at $z=-29 \mathrm{~m}$, about $2 \mathrm{~m}$ above the TBM crown, recorded the greatest $\Delta u$. As observed for the westbound tunnel construction, although the lowest three piezometers in HP33 were interconnected, it seems that the immediate pore water pressure responses to eastbound tunnel construction were still measured independently.
Response of HP34 piezometers (TBM2, period 4)

Pore water pressure changes measured within HP34 in response to eastbound tunnel construction, as shown in Figs 11(a)-11(c), were much smaller than those of HP32 and HP33, it being further away from TBM2 (18.6 m horizontally from its centre-line). Only the deepest sensor at $z=-29 \mathrm{~m}$ measured a gradual increase of pore water pressure up to $+8 \mathrm{kPa}$ during the passage of TBM2. Negligible changes were registered by the piezometers at other depths. The magnitude of the $\Delta u$ response is even smaller than that measured within HP33 in response to the westbound tunnel construction (cf. Fig. 6). A likely reason for the smaller response at HP34 is the combined presence of the existing Central Line tunnel (see Fig. 1) and, perhaps more predominantly, the newly constructed Crossrail westbound tunnel. Both are stiffer than the ground and hence 'attract' more total stress changes induced by the eastbound tunnel construction. As a result the ground at HP34 would

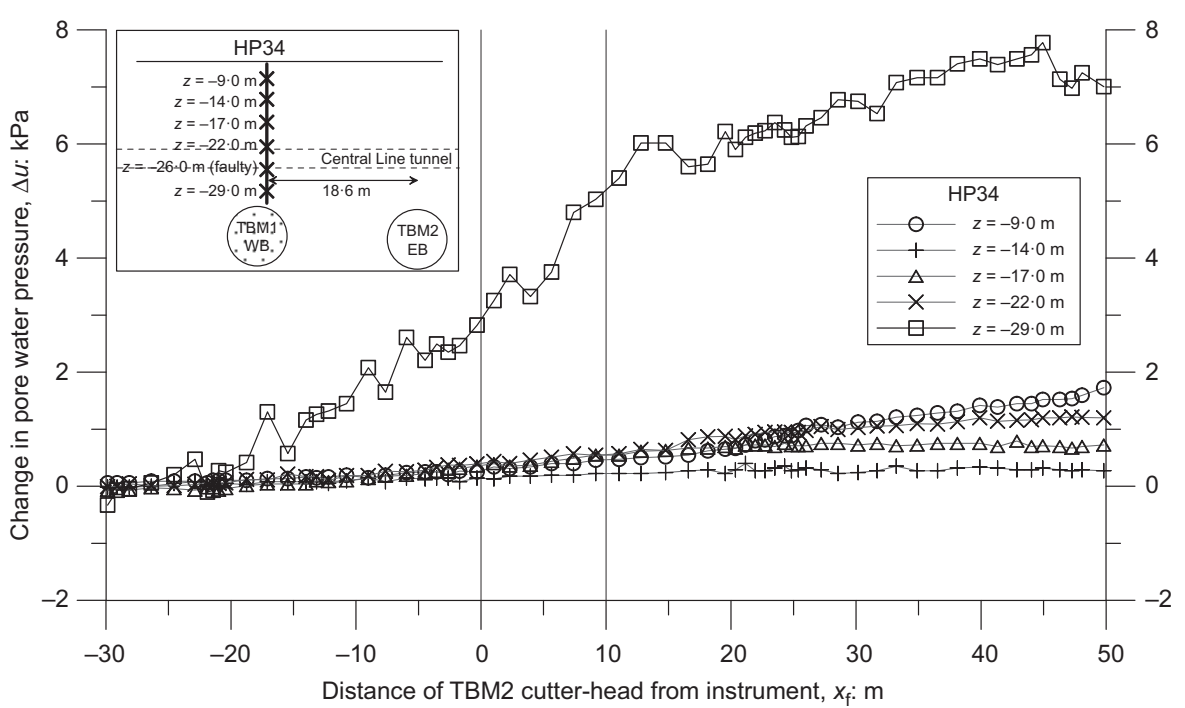

(a)

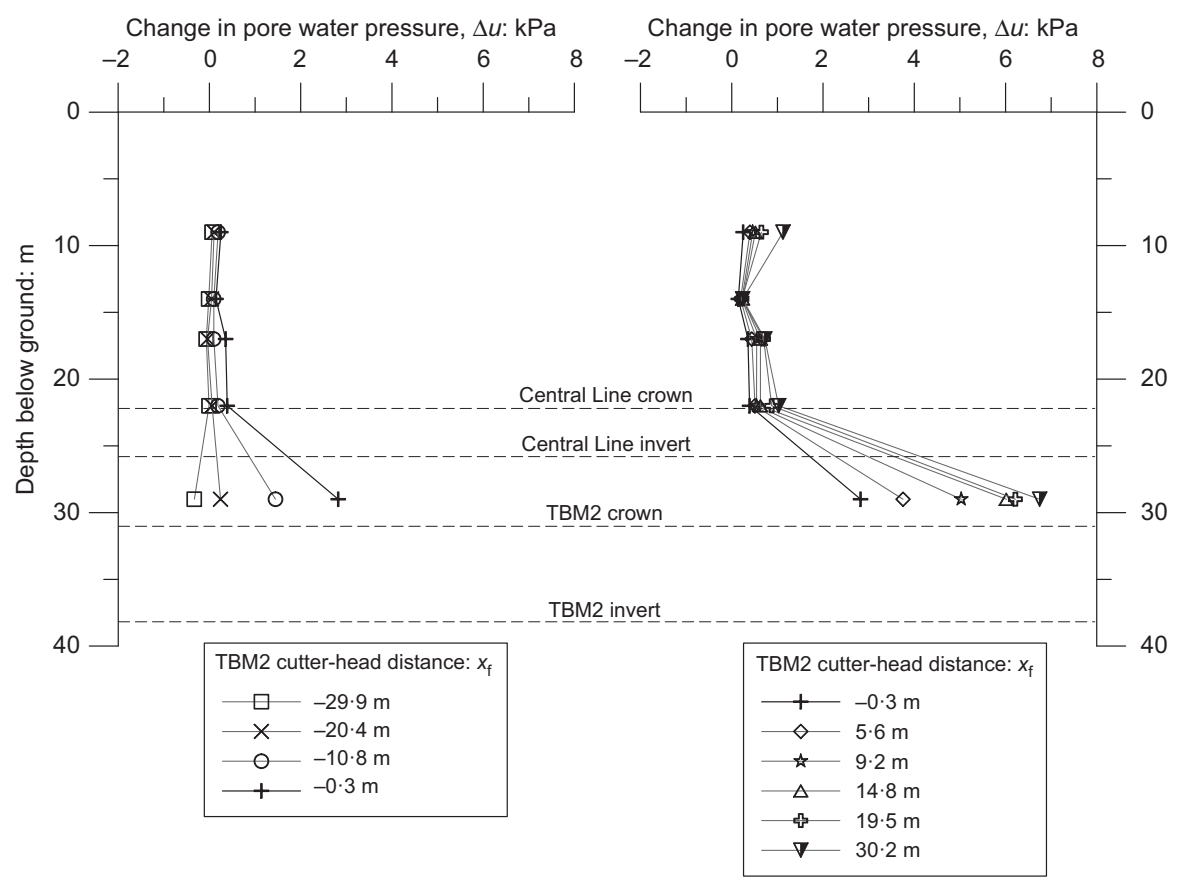

(b)

(c)

Fig. 11. Change in pore water pressure measured in piezometer HP34 in response to eastbound construction (period 4): (a) variation with TBM2 cutter-head distance; (b) depth profiles when the TBM2 cutter-head was approaching the instrument; (c) depth profile when TBM2 cutter-head was leaving the instrument 
have experienced a smaller total stress change (and hence smaller excess pore water pressure) than the 'greenfield' ground at HP33 when the westbound tunnel was being constructed.

\section{Response of spade cells HP35, HP36, HP37 and HP39 (TBM2, period 4)}

Data from the measurements of $\Delta u$ and $\Delta \sigma_{\mathrm{h}}$ from the spade cells in response to the eastbound tunnel construction are presented in Fig. 12. The data-loggers serving HP36 and HP37 became faulty during the tunnel construction period and so measurements were taken manually three to four times a day using a hand-held VW readout device and thus some critical readings might have been missed (compared with the hourly data logging). As shown in Fig. 12(a), values of $\Delta u$ measured about $1.5 \mathrm{~m}$ either side of the eastbound tunnel extrados (HP35 and HP36) and about $2 \mathrm{~m}$ above the eastbound tunnel crown (HP39) showed almost the same pattern, with very slight increases (up to $+5 \mathrm{kPa}$ ) as the cutter-head approached them (average face pressure $=$ $200 \mathrm{kPa}$ ), followed by a consistent reduction of pore water pressure as TBM 2 passed. The magnitudes of change were much larger than for TBM1, as with the TBM2 drive the relative distances were much closer, but the sense of change was completely opposite with decreasing pore water pressures observed compared with the increases seen when TBM1 passed. This suggests that the effects of unloading and shearing are much greater in the close vicinity of the TBM (TBM2 in this case, around which the instruments were closely clustered). Additionally, the rebound of pore water pressure, induced by the tail grouting as observed within the piezometers in HP32 and HP33 at corresponding $y-z$ positions at $x_{\mathrm{f}}=10 \mathrm{~m}$ was not observed. In this case the pore water pressure responses measured at the spade cells do not seem as sensitive as those measured by the multi-level piezometers (HP32 to HP34). The reason for this is not known but might be associated with the contact condition (e.g. smeared or voided interface) between the soil and the piezometer filter on the spade surface. The final reduction in pore water pressure at these spade cell locations was about $-100 \mathrm{kPa}$. Values of $\Delta u$ measured by spade cell HP37 further away from TBM2 show responses of much smaller magnitude, being less than $\pm 5 \mathrm{kPa}$ and so almost negligible. It is worth noting that, despite the difference in sensitivity, the magnitudes of the final change of pore water pressure after TBM2 has passed $\left(x_{\mathrm{f}}=60 \mathrm{~m}\right)$ measured by the deepest piezometer of HP33 and the spade cell HP39 (at the same relative position to TBM2) were comparable to each other, being about $100-115 \mathrm{kPa}$.

There is a marked $\Delta u$ reduction of up to $20 \mathrm{kPa}$ measured in HP35, HP36 and HP39 at about $x_{\mathrm{f}}=40 \mathrm{~m}$, which again is associated with a period when the TBM advance slowed down (clustering of hourly readings). However, at the same time the corresponding $\Delta \sigma_{\mathrm{h}}$ values (transverse to the tunnel axis) measured by these spade cells were much less pronounced. This might imply that the marked changes in pore water pressure at $x_{\mathrm{f}}=40 \mathrm{~m}$ originated mainly from the total horizontal stress change in the direction parallel to the tunnel axis.

An increase of total horizontal stress of up to $+80 \mathrm{kPa}$ was measured in HP35 prior to the cutter-head reaching the
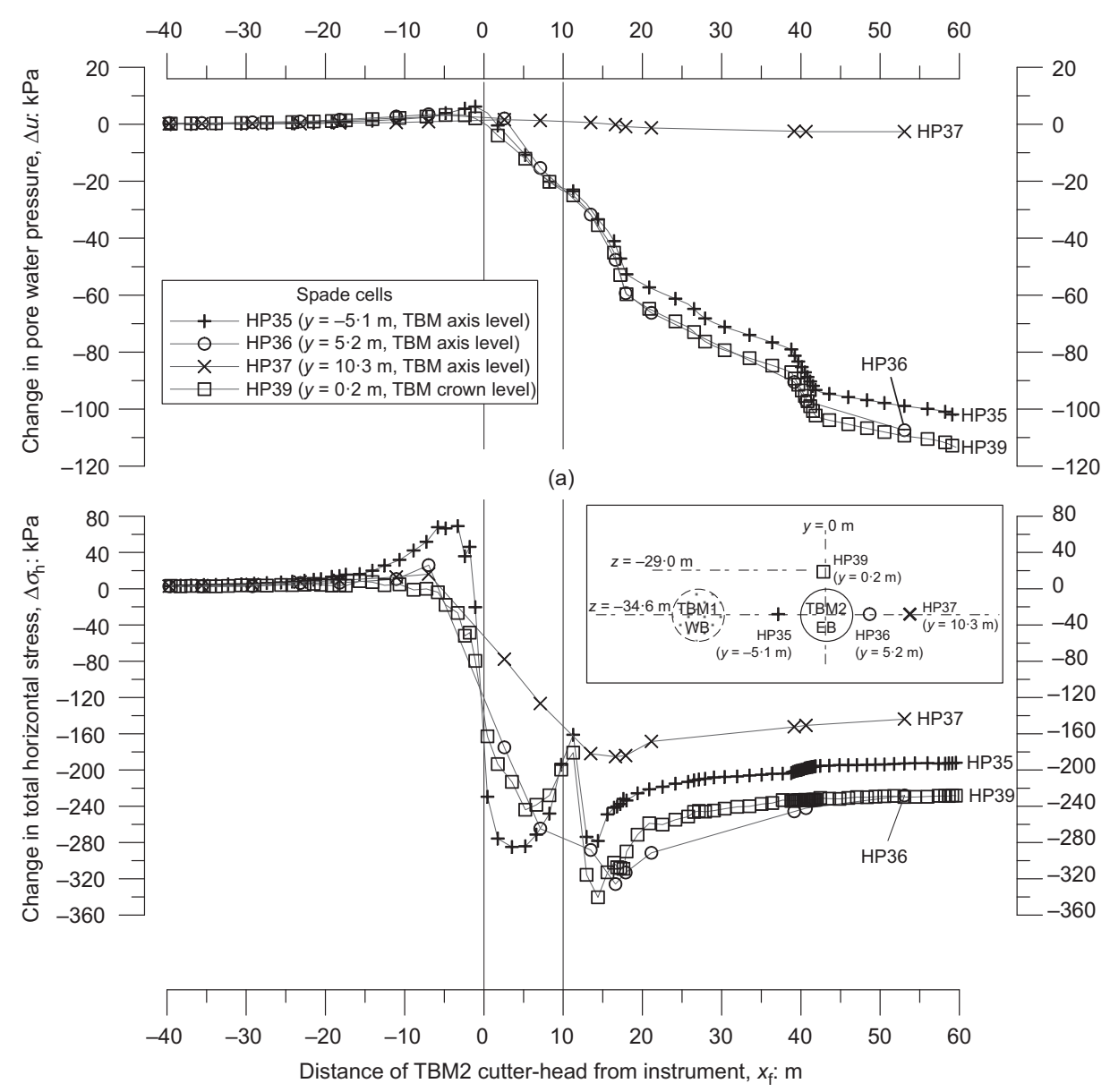

(b)

Fig. 12. Change in (a) pore water pressure and (b) total horizontal stress measured in spade cells HP35, HP36, HP37 and HP39 in response to eastbound construction (period 4) 
spade cells, probably as a result of the development of ground arching ahead of the approaching cutter-head (Fig. 12(b)). Very small total stress increases can be observed from the manual measurements at the other spade cell HP36, at the same offset but on the other (northern) side of the tunnel extrados, but no manual measurements were made at the time when the peak was observed in HP35. It therefore seems likely that greater $\Delta \sigma_{\mathrm{h}}$ values would have been observed at HP36, and perhaps HP37 (but judging from the trends, not to the same degree as HP35). However, no total horizontal stress increase was measured in the spade cell HP39 (hourly data-logged) directly above TBM 2 crown, as might have been anticipated.

All four spade cells recorded a reduction in total horizontal stress as the TBM2 cutter-head reached them $\left(x_{\mathrm{f}}=0 \mathrm{~m}\right)$, as a consequence of ground loss and stress relief due to the excavation. Readings from both HP35 and HP39 indicate a rebound of total stress between $5 \mathrm{~m}<x_{\mathrm{f}}<10 \mathrm{~m}$ from tail grouting and the development of ground arching, reaching a peak, followed by a further drop between $10 \mathrm{~m}<x_{\mathrm{f}}<15 \mathrm{~m}$ as the ground closed in towards the newly erected lining. It appears from the data available for HP36, and perhaps HP37, that the same trends would have been observed but have been missed because of the much lower frequency of manual measurements. Total stresses recovered partly as TBM2 advanced further from $15 \mathrm{~m}<x_{\mathrm{f}}$ $<20 \mathrm{~m}$ as a result of the tail grout setting and gaining stiffness, after which they stabilised.

Further interpretation. Qualitative comparisons can again be made between trends in $\Delta \sigma_{\mathrm{h}}$ and the corresponding changes in displacement, referring to the observations of Wan et al. (2017b). Vertical displacements at axis level were small, being less than $6 \mathrm{~mm}$, as measured from extensometer HP24 (Wan et al., 2017b: Fig. 8), which is at the same offset as HP36, and unlikely to have a significant influence on changes in horizontal total stress. It is interesting to note that the ground at the level of spade cell HP39, above the crown of TBM2, displaced downwards by about $23 \mathrm{~mm}$, as measured by extensometer HP23. It seems likely that the spade cell displaced together with the ground resulting in negligible interaction effects from interface shearing. In terms of horizontal displacements, the reversal of ground movements at axis level that was observed for TBM1 is much less pronounced for comparative measurements for TBM2 (Wan et al., 2017b: Fig. 10(b) cf. Fig. 12(b)). Despite this, as described above, in terms of $\Delta \sigma_{\mathrm{h}}$ measurements, the rebound in total stress at axis level from tail grouting is very evident $\left(5 \mathrm{~m}<x_{\mathrm{f}}<10 \mathrm{~m}\right.$, Fig. 12(b)). Horizontal displacements towards TBM2 as its tail passed inclinometer HP9 were greater than for TBM1 (measured within HP6 at same offset), being about $26 \mathrm{~mm}$ as opposed to $17 \mathrm{~mm}$ (refer to Figs 11 and 14 in the paper by Wan et al. (2017b)). This can be attributed to ground softening from the construction of TBM1, as discussed by the authors in the earlier paper. It is also evident from these same figures (Wan et al., 2017b: Figs. 11 and 14) how sensitive magnitudes of changes in displacement are to the distance from the tunnel extrados. Based on the observation above concerning rebound, a similar or even greater sensitivity would be expected in terms of stress changes.

The final reduction in total horizontal stress at spade cell HP36 $(y=5 \cdot 2 \mathrm{~m})$ was about $-230 \mathrm{kPa}$; larger in magnitude than that at HP35 $(y=-5 \cdot 1 \mathrm{~m})$ which was about $-190 \mathrm{kPa}$. This asymmetric response is most likely to be due to the construction and presence of the westbound tunnel, but could also be influenced by spade cell installation effects

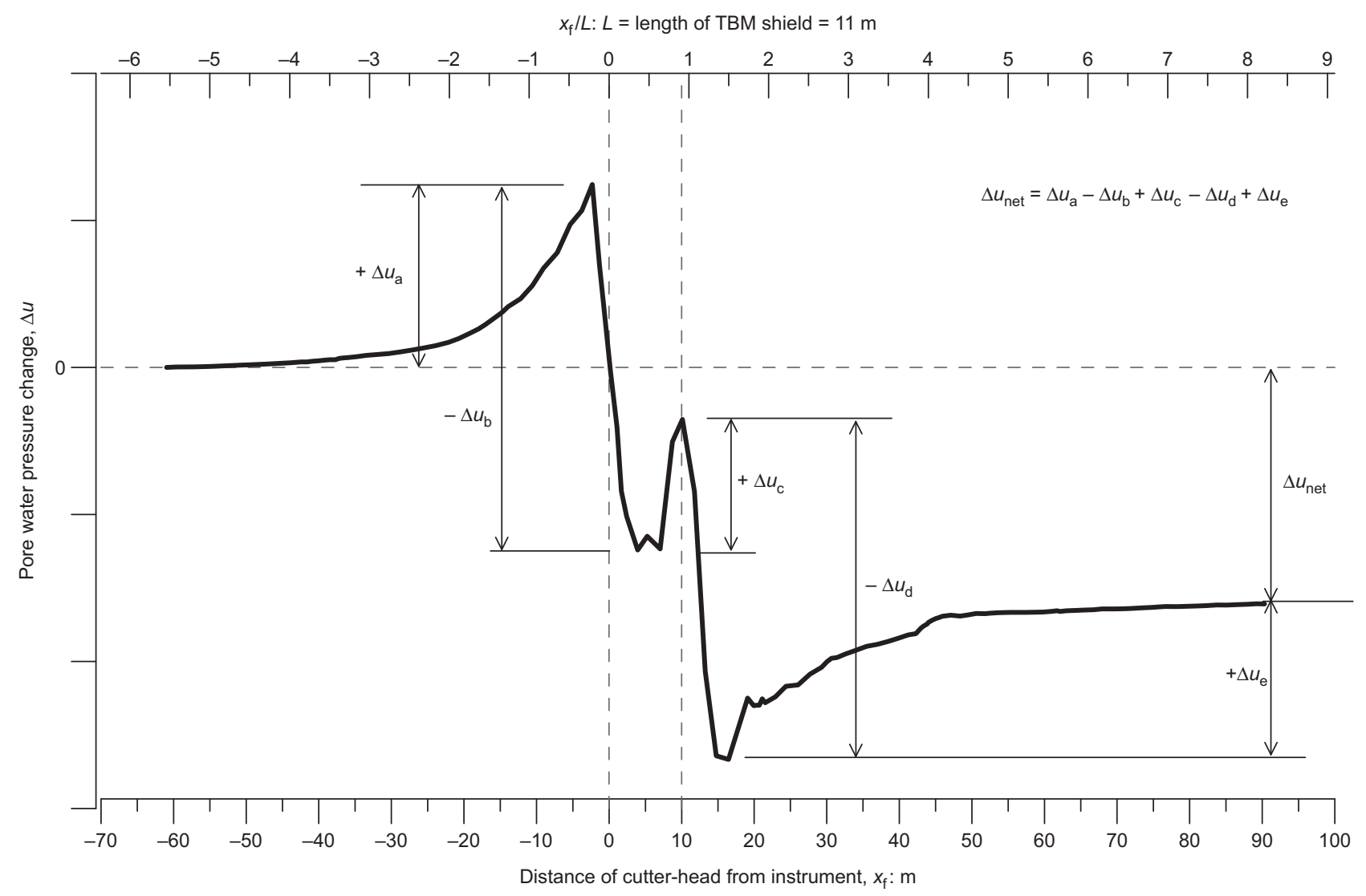

Fig. 13. Typical components of pore water pressure changes in relation to EPBM operations 
(e.g. deviation of spade orientation from the intended direction). Spade cell, HP37, also at axis level but further away from TBM2 $(y=10 \cdot 3 \mathrm{~m})$, recorded a smaller final reduction of about $-140 \mathrm{kPa}$, while that at spade cell HP39, $2 \mathrm{~m}$ above the TBM2 crown, was about $-230 \mathrm{kPa}$.

These measured net horizontal stress reductions of up to about $-230 \mathrm{kPa}$, immediately above and at either side of the excavation, constitute up to one third of the estimated in situ total overburden stress at the tunnel axis level $(650 \mathrm{kPa}$ approximately) - that is, representing about $35 \%$ of it in the immediate short term.

\section{MECHANISMS OF EPBM TUNNELLING-INDUCED PORE WATER PRESSURE CHANGES AND \\ GROUND ARCHING}

By examining the immediate ground response in the close vicinity of the TBMs during their passage, a general pattern of pore water pressure changes can be formulated. The development of the pressure changes can be broadly divided into five stages/components in relation to the relative distance to the EPBM shield, as shown in Fig. 13 (typified by the response of the sensors at $z=-31.0 \mathrm{~m}$ and $-37.2 \mathrm{~m}$ in Fig. 9(a)). It is also instructive to relate these typical components to the effects of: $(a)$ stress relief induced by ground losses at the cutter-head and tail void; $(b)$ development of ground arching in front of the cutter-head (referred to as 'domed' arching) and along the shield body (referred to as 'longitudinal' arching) over softened ground that was subjected to greater ground losses; and (c) tail grout pressure compressing the ground around the tail skin. These effects and the postulated development of ground arching at different positions of an advancing EPBM are shown schematically in Fig. 14.

The five components of pore water pressure changes, as shown in Fig. 13, the ranges over which they develop and their main causes, as postulated in Fig. 14, are described below.

(a) The pore water pressure increases by an amount of $+\Delta u_{\mathrm{a}}$ when the cutter-head approaches, first due to the development of the 'domed' arching and then the 'longitudinal' arching around the cutter-head $\left(x_{\mathrm{f}}<-2 \mathrm{~m}\right.$ approximately).

(b) It is followed by a reduction of $-\Delta u_{\mathrm{b}}$ induced by the stress relief as the cutter-head excavates and over-cuts the ground in the close proximity of the instrument location $\left(-2 \mathrm{~m}<x_{\mathrm{f}}<5 \mathrm{~m}\right.$ approximately).

(c) The pore water pressure then undergoes a rebound of $+\Delta u_{\mathrm{c}}$ induced by the application of tail grout pressure and also development of the 'longitudinal' arch (occurring in advance of the tail skin, $7 \mathrm{~m}<x_{\mathrm{f}}<10 \mathrm{~m}$ approximately).

(d) As the shield tail progresses beyond the instrument, the pressure drops further by $-\Delta u_{\mathrm{d}}$ induced by the stress relief associated with the tail void closure $\left(10 \mathrm{~m}<x_{\mathrm{f}}<15 \mathrm{~m}\right.$ approximately).

(e) Finally, the pressure recovers partly by $+\Delta u_{\mathrm{e}}$ upon the development of a second 'longitudinal' arching

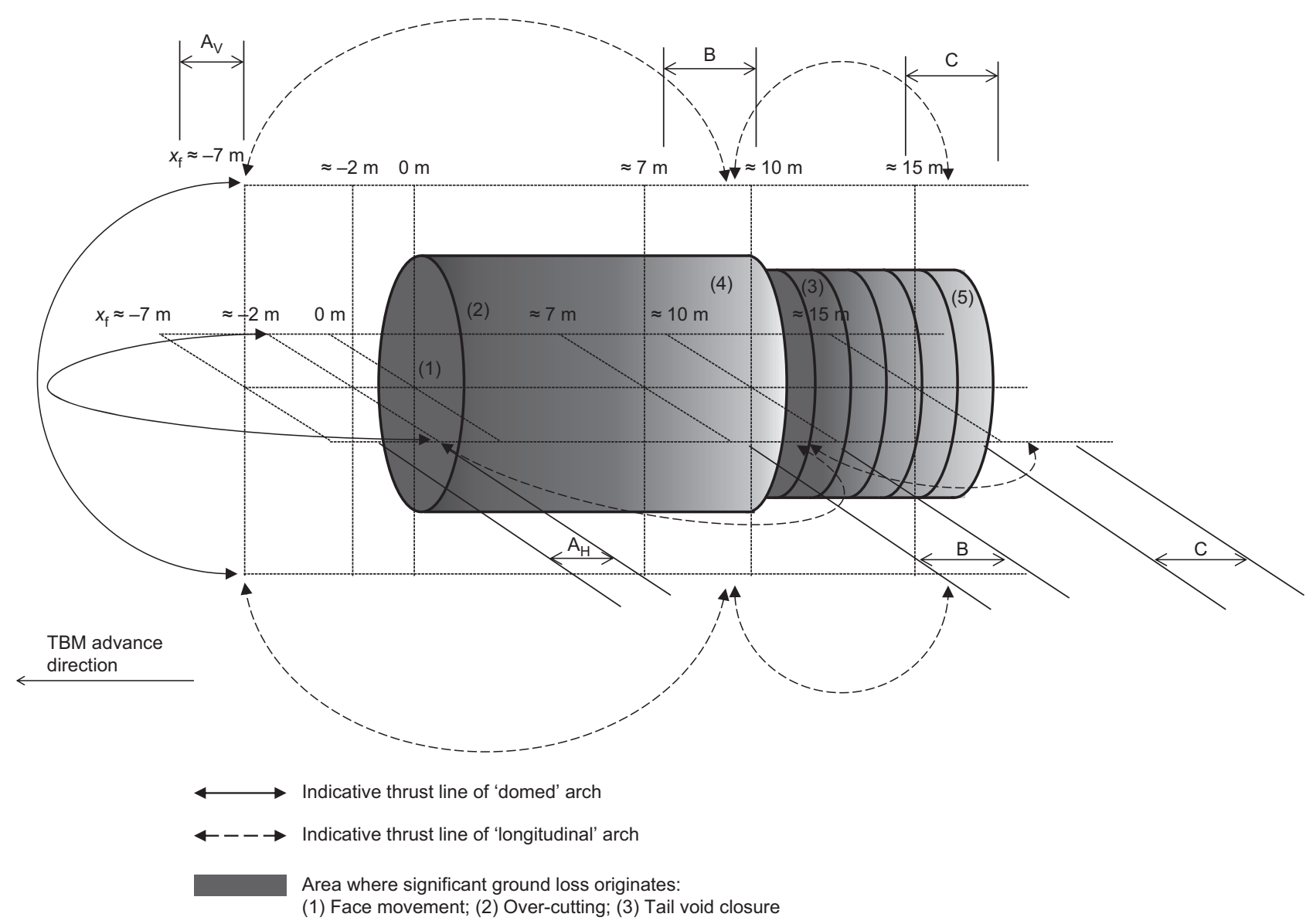

Area where the ground gains support:

(4) Tail grout pressure; (5) Tail grout gaining stiffness

Fig. 14. Schematic representation of development of ground arching around TBM shield 
mechanism behind the shield tail on the tunnel linings after the tail grout sets and increases in stiffness $\left(x_{\mathrm{f}}>15 \mathrm{~m}\right)$.

(f) The net pressure change $\Delta u_{\text {net }}$ is the arithmetic sum of these components.

By further examining the pore water pressure changes in the vicinity of the eastbound tunnel construction measured by the piezometers in HP32 and HP33 (Fig. 15), the spatial variation in the transverse plane of these five components can be interpreted. The deepest two piezometers at $z=-26.0 \mathrm{~m}$ and $z=-29 \cdot 1 \mathrm{~m}$ of HP33 were located vertically above the crown; the two piezometers at $z=-31.0 \mathrm{~m}$ and $z=-37.2 \mathrm{~m}$ of HP32 measure pore water pressures at the side of the tunnel; the deepest piezometer at $z=-42.0 \mathrm{~m}$ of HP32 is assumed to measure pressures representative of that vertically below the tunnel invert.

The initial pore water pressure increase $+\Delta u_{\mathrm{a}}$ peaked at about $x_{\mathrm{f}}=-7 \mathrm{~m}$ above the crown and below the invert but at about $x_{\mathrm{f}}=-2 \mathrm{~m}$ at the side. The ranges over which the vertical and horizontal arching spring-lines would develop are marked as ranges $A_{V}$ and $A_{H}$, respectively, in Figs 14 and 15 , beyond which the ground would be greatly softened by the cutter-head face movement. Inspection of the field displacement measurements shows that there were greater measured vertical displacements compared with the horizontal displacements at the same radial offset (see Fig 8(a) (HP23) and Fig. 10(a) in the paper by Wan et al. (2017b)), implying that the ground ahead of the cutter-head was softened to a larger extent vertically than horizontally. It can therefore be inferred that the common arching spring-lines (the stiffer 'stationary' points in the ground) from which the 'domed' and 'longitudinal' arching mechanisms emanate in front of the cutter-head were further apart vertically than horizontally. This helps explain why, in front of the cutterhead, the measured pore water pressure above and below it started to drop earlier than at the side. Another potential explanation for this is that as the ground ahead of the cutter-head moved into the shield face, a proportion of the vertical stress above the projection of the tunnel crown was transferred to the sides, resulting in a reduction of the pore water pressure above the crown and an increase of the pore water pressure at the sides.

The subsequent pressure drop $-\Delta u_{\mathrm{b}}$ would continue until the instruments were roughly midway along the length of the shield body $\left(x_{\mathrm{f}} \approx 5 \mathrm{~m}\right)$. The pressure rebound $+\Delta u_{\mathrm{c}}$ would then peak at between $7 \mathrm{~m}<x_{\mathrm{f}}<10 \mathrm{~m}$ (referred to as range $\mathrm{B}$ in Figs 14 and 15) before the further pressure drop $-\Delta u_{\mathrm{d}}$ occurring until $x_{\mathrm{f}} \approx 15 \mathrm{~m}$ (range $\mathrm{C}$ ). These ranges $\mathrm{B}$ and $\mathrm{C}$ correspond to the stiffer 'stationary' points in the ground from which the 'longitudinal' arching spring-lines behind the cutter-head were developed. It can be seen that behind the cutter-head $\left(x_{\mathrm{f}}>0 \mathrm{~m}\right)$, the same pattern of pore water pressure change seems to develop regardless of the measurement positions relative to the TBM in the transverse plane (above, below or at the side). This indicates that the tunnel axis, being at $35 \mathrm{~m}$ or five times the excavation diameter below ground surface, was deep enough that the measured pore water pressure response showed no significant preference over any particular direction in the transverse plane. As such the pressure change (and ground movements) around the shield body (behind the cutter-head) and the erected linings would resemble that of a collapsing cylindrical cavity in an isotropic ground, as suggested by Mair \& Taylor (1993).

Variations in the five different components of pore water pressure change with the radial distance from the tunnel axis,

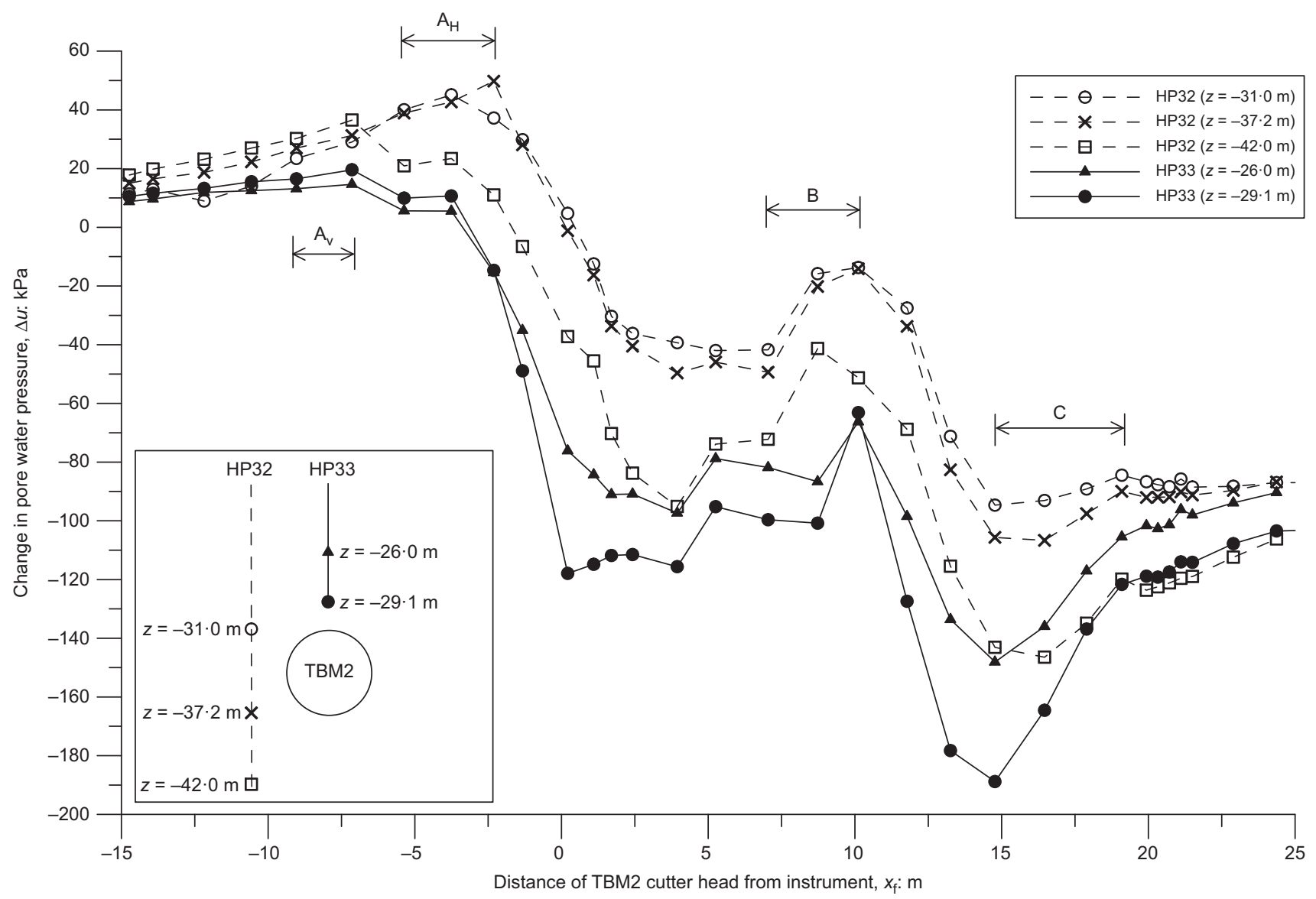

Fig. 15. Change in pore water pressure measured in piezometers HP32 and HP33 in the vicinity of the eastbound construction (period 4) 
as well as the net pore water pressure change, are depicted in Figs 16(a)-16(f). In general, the magnitude of the pressure change decreases with increasing distance from the tunnel. The immediate response induced by the different stages of EPBM operation became insignificant at a radial distance greater than about three excavation diameters from the tunnel axis (i.e. $6 R$ ).

The lower bounds for the absolute responses of different components of pore water pressure changes are almost always formed by the data points for HP34 in Fig. 16. One reason for the smaller response at HP34 could be the presence of the existing Central Line tunnel 'attracting' more of the total stress change induced by the Crossrail tunnel construction. As a result the ground at HP34 would experience a smaller total stress change (and hence excess pore water pressure) than the 'greenfield' ground at HP32 and HP33. In a similar manner, the presence of the existing Central Line tunnel also helped explain the smaller subsurface ground settlements measured at extensometer HP26 near the Central Line tunnel than those at the extensometer HP20 in the 'greenfield' ground during the westbound construction (Wan et al., 2017b: Fig. 4) and also the smaller settlements measured at HP28 near the Central Line tunnel than at HP23 during the eastbound construction (Wan et al., 2017b: Fig. 8).

The non-isotropic response in front of the cutter-head in terms of the magnitudes of the component of pore water pressure increase $\left(+\Delta u_{\mathrm{a}}\right)$ is evident from Fig. 16(a), with the piezometers at the side (HP32) measuring a consistently greater pressure increase than those above the crown (HP33)

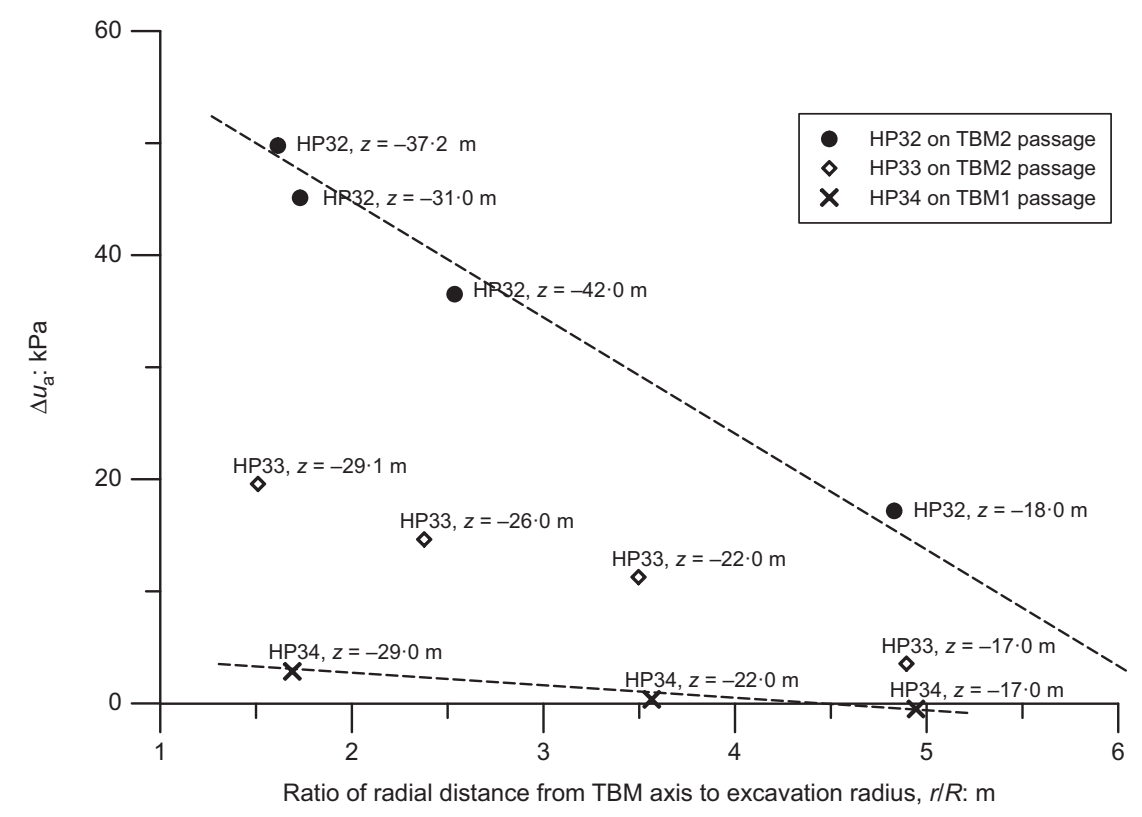

(a)

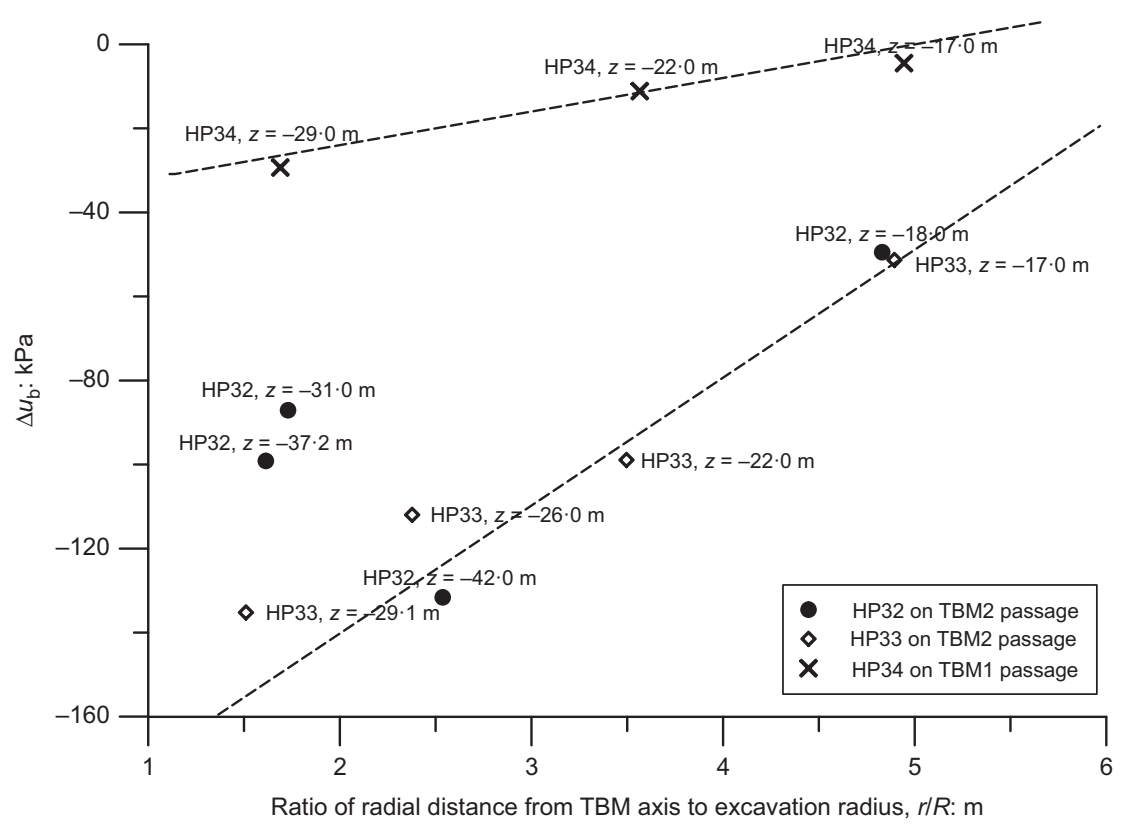

(b)

Fig. 16. Change of pore water pressure induced by: (a) TBM cutter-head approaching the instrument; (b) ground movement into TBM face and front of shield; (c) TBM tail approaching the instrument; (d) TBM tail void closure; (e) lining support. (f) Net change of pore water pressure induced by TBM passage (continued on next page) 


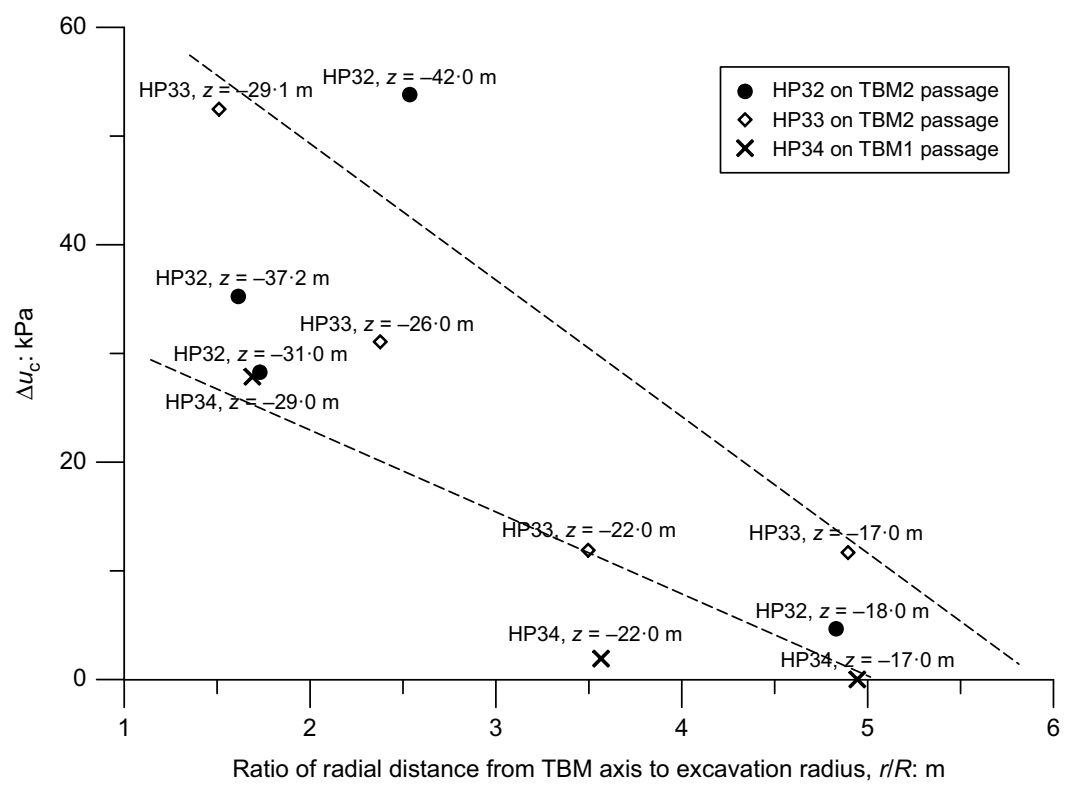

(c)

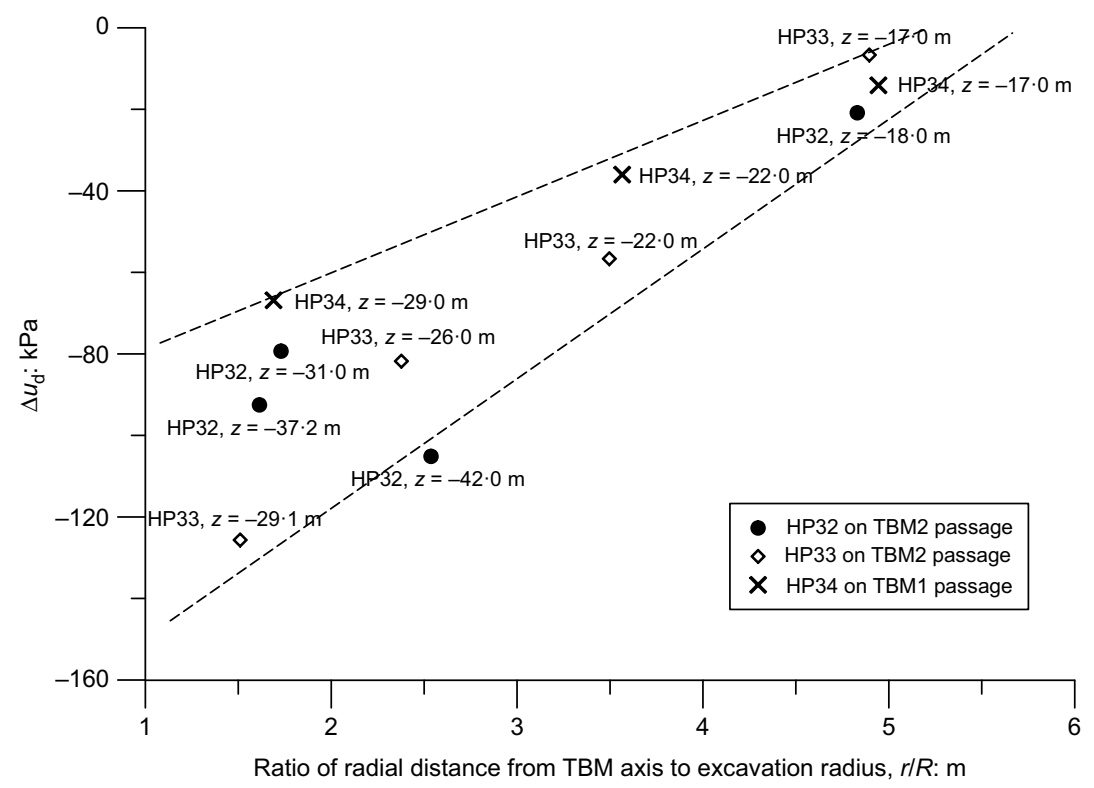

(d)

Fig. 16. Continued

at the same radial distance from the tunnel. However, the magnitudes of the other components of pressure increase measured behind the cutter-head, as shown in Figs 16(b)-16(e), indicate a more isotropic response. This corroborates the suggestion that the ground response to the tunnelling operations behind the cutter-head resembles that of a collapsing (or expanding) cylindrical cavity in an isotropic medium.

The different components of pressure changes induced by both the westbound and eastbound construction measured by the VW piezometers HP32 (TBM2), HP33 (TBM2) and HP34 (TBM1) are summarised in Tables 3-5.

\section{SUMMARY AND CONCLUSIONS}

The monitoring results of short-term pore water pressure and total horizontal stress changes induced by the twin-bore Crossrail tunnels measured at the Hyde Park instrumentation site have been presented and discussed. The key findings from the field measurement are as follows.

(a) The multi-level VW piezometers installed by the fully grouted method in boreholes near the tunnel construction were able to measure automatically, rapidly and independently the pore water pressure changes as the EPBM passed the instruments (even in cases where instruments had a degree of interconnectivity).

(b) A clear pattern of developing pore water pressure and total horizontal stress changes was observed as the EPBMs approached and left the instruments, with a number of components associated with the relative position of the shield from the instrument clearly identified. Excess pore water pressure and total horizontal stress changes in response to the development of ground arching 


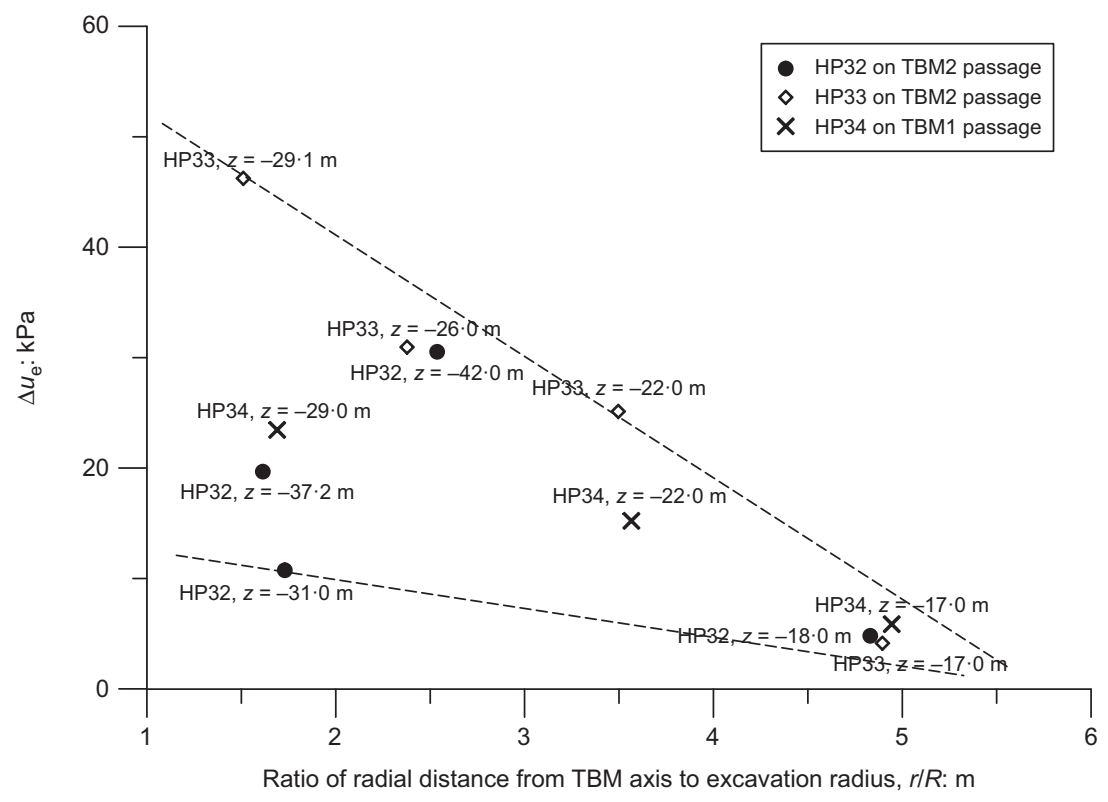

(e)

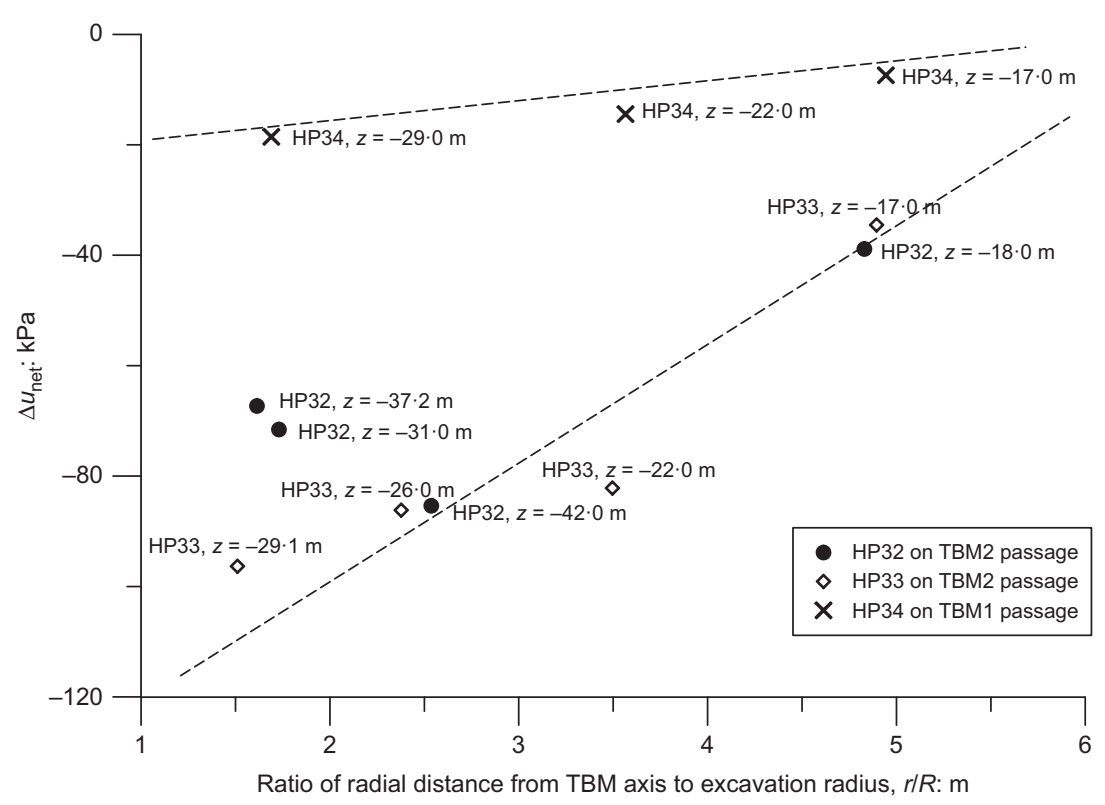

(f)

Fig. 16. Continued

in front of and along the shield, cutter-head excavation, tail grouting, tail void closure and lining support were measured. These, together with the subsurface vertical and horizontal ground displacements measured by the rod extensometers and inclinometers near the tunnel construction described in the companion paper (Wan et al., 2017b), help with the understanding of the mechanisms of near-tunnel ground response to EPBM tunnel construction.

(c) In particular, the ground arching mechanism, first postulated by Terzaghi (1943) and subsequently investigated numerically and experimentally by other researchers, around an advancing EPBM in stiff London Clay has been clearly identified and validated for the first time by field monitoring of changes in pore water pressure. (d) The measurements taken by the multi-level VW piezometers and the pushed-in spade cell piezometers show consistent trends of excess pore water pressure development. However, some aspects of response pertaining to the EPBM operations measured by the multilevel piezometers were not measured by the spade cells at the same relative positions to the tunnel construction, possibly due to the contact condition between the soil and the piezometer filter.

(e) The magnitudes of the different components of the pore water pressure changes associated with the EPBM operations were found to be decreasing with increasing distance from the excavation. The short-term effect of the EPBM construction in terms of the excess pore water pressure seems to be insignificant at a distance beyond three times the excavation diameter from the tunnel axis. 
Table 3. Components of pore water pressure changes induced by eastbound construction (TBM2 passage) measured by HP32

\begin{tabular}{|c|c|c|c|c|c|c|c|}
\hline \multirow{2}{*}{$\begin{array}{l}\text { Depth below } \\
\text { ground: } m\end{array}$} & \multirow{2}{*}{$\begin{array}{l}\text { Radial distance from } \\
\text { tunnel axis: } \mathrm{m}\end{array}$} & \multicolumn{5}{|c|}{ Components of pore water pressure change: $\mathrm{kPa}$} & \multirow{2}{*}{$\begin{array}{l}\text { Net pore water pressure } \\
\text { change } \Delta u_{\text {net }}: \mathrm{kPa}\end{array}$} \\
\hline & & $\Delta u_{\mathrm{a}}$ & $\Delta u_{\mathrm{b}}$ & $\Delta u_{\mathrm{c}}$ & $\Delta u_{\mathrm{d}}$ & $\Delta u_{\mathrm{e}}$ & \\
\hline $\begin{array}{l}18 \cdot 0 \\
31 \cdot 0 \\
37 \cdot 2 \\
42 \cdot 0\end{array}$ & $\begin{array}{r}17 \cdot 3 \\
6 \cdot 2 \\
5 \cdot 8 \\
9 \cdot 1\end{array}$ & $\begin{array}{l}17 \cdot 2 \\
45 \cdot 1 \\
49 \cdot 8 \\
36 \cdot 5\end{array}$ & $\begin{array}{r}-49 \cdot 5 \\
-87 \cdot 1 \\
-99 \cdot 2 \\
-131 \cdot 6\end{array}$ & $\begin{array}{r}4 \cdot 7 \\
28 \cdot 3 \\
35 \cdot 2 \\
53 \cdot 8\end{array}$ & $\begin{array}{r}-20 \cdot 8 \\
-79 \cdot 3 \\
-92 \cdot 5 \\
-105 \cdot 1\end{array}$ & $\begin{array}{r}9 \cdot 6 \\
21 \cdot 5 \\
39 \cdot 3 \\
61 \cdot 0\end{array}$ & $\begin{array}{l}-38 \cdot 9 \\
-71 \cdot 6 \\
-67 \cdot 3 \\
-85 \cdot 4\end{array}$ \\
\hline
\end{tabular}

Table 4. Components of pore water pressure changes induced by eastbound construction (TBM2 passage) measured by HP33

\begin{tabular}{|c|c|c|c|c|c|c|c|}
\hline \multirow{2}{*}{$\begin{array}{l}\text { Depth below } \\
\text { ground: } m\end{array}$} & \multirow{2}{*}{$\begin{array}{l}\text { Radial distance from } \\
\text { tunnel axis: } m\end{array}$} & \multicolumn{5}{|c|}{ Components of pore water pressure change: $\mathrm{kPa}$} & \multirow{2}{*}{$\begin{array}{l}\text { Net pore water pressure } \\
\text { change } \Delta u_{\text {net }}: \mathrm{kPa}\end{array}$} \\
\hline & & $\Delta u_{\mathrm{a}}$ & $\Delta u_{\mathrm{b}}$ & $\Delta u_{\mathrm{c}}$ & $\Delta u_{\mathrm{d}}$ & $\Delta u_{\mathrm{e}}$ & \\
\hline $\begin{array}{l}17 \cdot 0 \\
22 \cdot 0 \\
26 \cdot 0 \\
29 \cdot 1\end{array}$ & $\begin{array}{r}17 \cdot 5 \\
12 \cdot 5 \\
8 \cdot 5 \\
5 \cdot 4\end{array}$ & $\begin{array}{r}3 \cdot 5 \\
11 \cdot 3 \\
14 \cdot 6 \\
19 \cdot 6\end{array}$ & $\begin{array}{r}-51 \cdot 3 \\
-98 \cdot 9 \\
-112 \cdot 0 \\
-135 \cdot 2\end{array}$ & $\begin{array}{l}11 \cdot 7 \\
11 \cdot 9 \\
31 \cdot 1 \\
52 \cdot 5\end{array}$ & $\begin{array}{r}-6 \cdot 7 \\
-56 \cdot 6 \\
-81 \cdot 8 \\
-125 \cdot 7\end{array}$ & $\begin{array}{r}8 \cdot 3 \\
50 \cdot 2 \\
61 \cdot 9 \\
92 \cdot 5\end{array}$ & $\begin{array}{l}-34 \cdot 5 \\
-82 \cdot 2 \\
-86 \cdot 2 \\
-96 \cdot 4\end{array}$ \\
\hline
\end{tabular}

Table 5. Components of pore water pressure changes induced by westbound construction (TBM1 passage) measured by HP34

\begin{tabular}{|c|c|c|c|c|c|c|c|}
\hline \multirow{2}{*}{$\begin{array}{l}\text { Depth below } \\
\text { ground: } m\end{array}$} & \multirow{2}{*}{$\begin{array}{l}\text { Radial distance from } \\
\text { tunnel axis: } m\end{array}$} & \multicolumn{5}{|c|}{ Components of pore water pressure change: $\mathrm{kPa}$} & \multirow{2}{*}{$\begin{array}{l}\text { Net pore water pressure } \\
\text { change } \Delta u_{\text {net }}: \mathrm{kPa}\end{array}$} \\
\hline & & $\Delta u_{\mathrm{a}}$ & $\Delta u_{\mathrm{b}}$ & $\Delta u_{\mathrm{c}}$ & $\Delta u_{\mathrm{d}}$ & $\Delta u_{\mathrm{e}}$ & \\
\hline $\begin{array}{l}17 \cdot 0 \\
22 \cdot 0 \\
29 \cdot 0\end{array}$ & $\begin{array}{r}17 \cdot 7 \\
12 \cdot 7 \\
6 \cdot 0\end{array}$ & $\begin{array}{r}-0.5 \\
0 \cdot 4 \\
2 \cdot 9\end{array}$ & $\begin{array}{r}-4 \cdot 5 \\
-11 \cdot 1 \\
-29 \cdot 3\end{array}$ & $\begin{array}{r}0 \cdot 0 \\
1 \cdot 9 \\
27 \cdot 9\end{array}$ & $\begin{array}{l}-14 \cdot 1 \\
-36 \cdot 0 \\
-66 \cdot 9\end{array}$ & $\begin{array}{l}11 \cdot 7 \\
30 \cdot 4 \\
46 \cdot 9\end{array}$ & $\begin{array}{r}-7 \cdot 4 \\
-14 \cdot 4 \\
-18 \cdot 6\end{array}$ \\
\hline
\end{tabular}

( $f$ ) The presence of the existing Central Line tunnels near HP34 is likely to be the reason for the smaller magnitude of the short-term pore water pressure response to the westbound tunnel construction measured compared with those measured in 'greenfield' ground at HP32 and HP33 in response to the eastbound construction.

\section{ACKNOWLEDGEMENTS}

The authors wish to acknowledge the Engineering and Physical Sciences Research Council (EPSRC) (EP/G063486/1) and Crossrail who were the major sponsors for this field component of the research project. Many thanks are due to the Imperial College research team, especially the Imperial College technician $\mathrm{Mr}$ Alan Bolsher, and those others who helped take the field measurements during the $24 \mathrm{~h}$ surveying periods. A thoughtful review of the instrumentation plan by $\mathrm{Mr}$ John Dunnicliff is also greatly appreciated. The support provided by the Royal Parks, London Underground Limited and Westminster Council during the installation work is gratefully acknowledged. The specialist input and effort during the piezometer installation by itmsoil are very much appreciated. The authors are also grateful to the main joint venture contractors BFK, in particular Mr Ivor Thomas, for providing data and information relating to the EPBMs and their operation variables.

\section{REFERENCES}

Afshan, S., Yu, J. B. Y., Standing, J. R., Vollum, R. L. \& Potts, D. M. (2017). Ultimate capacity of a segmental grey cast iron tunnel lining ring subjected to large deformations. Tunnelling Underground Space Technol. 64, 74-84.
Avgerinos, V., Potts, D. M. \& Standing, J. R. (2016). The use of kinematic hardening models to predict tunnelling-induced soil movements in London Clay. Géotechnique 66, No. 2, 106-120, https://doi.org/10.1680/jgeot.15.P.035.

Avgerinos, V., Potts, D. M. \& Standing, J. R. (2017). Numerical investigation of the effects of tunnelling on existing tunnels. Géotechnique 67, No. 9, 808-822, https://doi.org/10.1680/jgeot. SiP17.P.103

Avgerinos, V., Potts, D. M., Standing, J. R. \& Wan, M. S.P. (2018). Predicting tunnelling-induced ground movements and interpreting field measurements using numerical analysis: Crossrail case study at Hyde Park. Géotechnique 68, No. 1, 31-49, https:// doi.org/10.1680/jgeot.16.P.219.

Barratt, D. A. \& Tyler, R. G. (1976). Measurements of ground movement and lining behaviour on the London Underground at Regents Park, Report no. LR684. Crowthorne, UK: Transport and Road Research Laboratory.

Burland, J. B., Simpson, B. \& St John, H. D. (1979). Movements around excavations in London Clay. In Proceedings of the 7th European conference on soil mechanics and foundation engineering, vol. 1, pp. 13-29. London, UK: British Geotechnical Society.

Clayton, C. R. I., Hope, V. S., Heymann, G., Van der Berg, J. P. \& Bica, A. V. D. (2000). Instrumentation for monitoring sprayed concrete lined soft ground tunnels. Proceedings of the Institution of Civil Engineers - Geotechnical Engineering 143, No. 3, 119-130, https://doi.org/10.1680/geng.2000.143.3.119.

Dival, S., Goodey, R. J. \& Stallebrass, S. E. (2017). Twin-tunnellinginduced changes to clay stiffness. Géotechnique 67, No. 10, 906-913, https://doi.org/10.1680/jgeot.sip17.P.151.

GCG (Geotechnical Consulting Group) (2009). Geotechnical sectional interpretative report $1 \& 2$ : Royal Oak to Liverpool Street, Report no. 1D0101-G0G00-00549, Revision A, prepared for Cross London Rail Links Ltd. London, UK: Geotechnical Consulting Group LLP.

Glossop, N. H. (1978). Soil deformations caused by soft-ground tunnelling. Doctoral dissertation, Durham University, Durham, UK. 
Grant, R. J. (1998). Movements around a tunnel in two-layer ground. Doctoral dissertation, City University London, London, UK.

Hwang, R. N., Wu, D. J. \& Lee, C. J. (1995). Pore pressure response to shield tunnelling in soft clay. In Proceedings of the South East Asian symposium on tunnelling and underground space development, pp. 33-40. Tokyo, Japan: Japan Tunnelling Association.

Jiang, M. \& Yin, Z. Y. (2012). Analysis of stress redistribution in soil and earth pressure on tunnel lining using the discrete element method. Tunnelling Underground Space Technol. 32, 251-259.

Jones, M. A. (2007). Rising groundwater in central London. Water Sewerage J. 4, 35-36.

King, C. (1981). The stratigraphy of the London Basin and associated deposits, Tertiary Research Special Paper. Rotterdam, the Netherlands: Backhuys.

Lee, C. J., Wu, B. R., Chen, H. T. \& Chiang, K. H. (2006). Tunnel stability and arching effects during tunneling in soft clayey soil. Tunnelling Underground Space Technol. 21, No. 2, 119-132.

Lee, K. M., Ji, H. W., Shen, C. K., Liu, J. H. \& Bai, T. H. (1999). Ground response to the construction of Shanghai metro tunnel-line 2. Soils Found. 39, No. 3, 113-134.

Lo, K. W., Chang, L. K., Leung, C. F., Lee, S. L., Makino, H. \& Mihara, T. (1988). Field measurements at a multiple tunnel interaction site. Proceedings of 2nd international symposium on field measurements in geomechanics, Kobe, Japan, vol. 2, pp. 881-889. Rotterdam, the Netherlands: AA Balkema.

Macklin, S. R. \& Field, G. R. (1999). The response of London Clay to full-face TBM tunnelling at West Ham, London. In Urban ground engineering (ed. B. Clarke), pp. 100-111. London, UK: Thomas Telford.

Mair, R. J. (1979). Centrifugal modelling of tunnelling construction in soft clay. $\mathrm{PhD}$ thesis, University of Cambridge, Cambridge, UK.

Mair, R. J. \& Taylor, R. N. (1993). Predictions of clay behaviour around tunnels using plasticity solutions. In Predictive soil mechanics (eds G. T. Houlsby and A. N. Schofield), pp. 449-463. London, UK: Thomas Telford.

New, B. M. \& Bowers, K. H. (1994). Ground movement model validation at the Heathrow Express trial tunnel. In Tunnelling '94, pp. 301-329. Dordrecht, the Netherlands: Springer.

Nyren, R. (1998). Field measurements above twin tunnels in London Clay. PhD thesis, Imperial College, University of London, London, UK.

Palmer, J. H. L. \& Belshaw, D. J. (1980). Deformations and pore pressures in the vicinity of a precast, segmented, concrete-lined tunnel in clay. Can. Geotech. J. 17, No. 2, 174-184.

Richards, D. J., Clark, J., Powrie, W. \& Heymann, G. (2007). Performance of push-in pressure cells in overconsolidated clay. Proceedings of the Institution of Civil Engineers - Geotechnical Engineering 160, No. 1, 31-41, https://doi.org/10.1680/geng. 2007.160.1.31

Ryley, M. D. \& Carder, D. R. (1995). The performance of push-in spade cells installed in stiff clay. Géotechnique 45, No. 3, 533-539, https://doi.org/10.1680/geot.1995.45.3.533.

Shirlaw, J. N. \& Doran, S. R. (1988). Ground movements and settlements caused by tunnelling for the Singapore mass rapid transit system. In Proceedings of Tunnelling '88, pp. 295-314. London, UK: Institution of Mining and Metallurgy.

Simpson, B., Blower, T., Craig, R. N. \& Wilkinson, B. R. (1989). The engineering implications of rising groundwater in the deep aquifer beneath London, Special Publication 69. London, UK: Ciria.

Standing, J. R. \& Selemetas, D. (2013). Greenfield ground response to EPBM tunnelling in London Clay. Géotechnique 63, No. 12, 989-1007, https://doi.org/10.1680/geot.12.P.154.

Standing, J. R., Potts, D. M., Vollum, R., Burland, J. B., Tsiampousi, A., Afshan, S., Yu, J. B. Y., Wan, M. S. P. \& Avgerinos, V. (2015). Investigating the effect of tunnelling on existing tunnels. In Proceedings of the conference on underground design and construction, pp. 301-312. Hong Kong, PR China: Institute of Materials, Minerals and Mining (Hong Kong Branch).

Tedd, P. \& Charles, J. A. (1981). In situ measurement of horizontal stress in overconsolidated clay using push-in spade-shaped pressure cells. Géotechnique 31, No. 4, 554-558, https://doi. org/10.1680/geot.1981.31.4.554.

Tedd, P. \& Charles, J. A. (1983). Evaluation of push-in pressure cell results in stiff clay. In Proceedings of the international symposium of soil and rock investigation by in-situ testing, vol. 2, pp. 579-584. Paris, France: International Association for Engineering Geology.

Tedd, P., Powell, J. J., Charles, J. A. \& Uglow, I. M. (1989). In-situ measurements of earth pressures using push-in spade-shaped pressure cells - 10 years' experience. In Geotechnical instrumentation in practice: purpose, performance and interpretation, pp. 701-715. London, UK: Thomas Telford.

Terzaghi, K. (1943). Theoretical soil mechanics. New York, NY, USA: John Wiley and Sons.

Tsiampousi, A., Yu, J., Standing, J. R., Vollum, R. \& Potts, D. M. (2017). Behaviour of bolted cast iron joints. Tunnelling Underground Space Technol. 68, 113-129.

Wan, M. S. P. (2014). Field monitoring of ground response to EPBM tunnelling close to existing tunnels in London Clay. $\mathrm{PhD}$ thesis, Imperial College London, London, UK.

Wan, M. S. P. \& Standing, J. R. (2014a). Lessons learnt from installation of field instrumentation. Proceedings of the Institution of Civil Engineers - Geotechnical Engineering 167, No. 5, 491-506, https://doi.org/10.1680/geng.13.00054.

Wan, M. S. P. \& Standing, J. R. (2014b). Field measurement by fully grouted vibrating wire piezometers. Proceedings of the Institution of Civil Engineers - Geotechnical Engineering 167, No. 6, 547-564, https://doi.org/10.1680/geng.13.00153.

Wan, M. S. P., Standing, J. R., Potts, D. M. \& Burland, J. B. (2017a). Measured short-term ground surface response to EPBM tunnelling in London Clay. Géotechnique 67, No. 5, 420-445, https://doi.org/10.1680/jgeot.16.P.099.

Wan, M. S. P., Standing, J. R., Potts, D. M. \& Burland, J. B. (2017b). Measured short-term subsurface ground response to EPBM tunnelling in London Clay. Géotechnique 67, No. 9, 748-779, https://doi.org/10.1680/jgeot.SIP17.P.148.

Wright, P. J. (2013). Validation of soil parameters for deep tube tunnel assessment. Proceedings of the Institution of Civil Engineers - Geotechnical Engineering 166, No. 1, 18-30, https://doi.org/10.1680/geng.9.00095.

Yi, X., Rowe, R. K. \& Lee, K. M. (1993). Observed and calculated pore pressures and deformations induced by an earth balance shield. Can. Geotech. J. 30, No. 3, 476-490.

Yu, J., Standing, J. R., Vollum, R., Potts, D. M. \& Burland, J. B. (2017). Experimental investigations of bolted segmental grey cast iron lining behaviour. Tunnelling Underground Space Technol. 61, 161-178. 